\title{
Identifying past social-ecological thresholds to understand long-term temporal dynamics in Spain
}

\author{
Fernando Santos-Martín ${ }^{1}$, Blanca González García-Mon ${ }^{2}$, José A. González $^{1}$, Irene Iniesta-Arandia ${ }^{3,4}$, Marina García-Llorente ${ }^{1,5}$, \\ $\underline{\text { Carlos Montes }}^{6}, \underline{\text { Federica Ravera }}^{4,7}$, Cesar A. López-Santiago $^{1}, \underline{\text { Óscar Carpintero }}^{8}, \underline{\text { Javier Benayas }}^{1}$ and Berta Martin-López $^{9}$
}

\begin{abstract}
A thorough understanding of long-term temporal social-ecological dynamics at the national scale helps to explain the current condition of a country's ecosystems and to support environmental policies to tackle future sustainability challenges. We aimed to develop a methodological approach to understand past long-term (1960-2010) social-ecological dynamics in Spain. First, we developed a methodical framework that allowed us to explore complex social-ecological dynamics among biodiversity, ecosystem services, human well-being, drivers of change, and institutional responses. Second, we compiled 21 long-term, national-scale indicators and analyzed their temporal relationships through a redundancy analysis. Third, we used a Bayesian change point analysis to detect evidence of past social-ecological thresholds and historical time periods. Our results revealed that Spain has passed through four socialecological thresholds that define five different time periods of nature and society relationships. Finally, we discussed how the proposed methodological approach helps to reinterpret national-level ecosystem indicators through a new conceptual lens to develop a more systems-based way of understanding long-term social-ecological patterns and dynamics.
\end{abstract}

Key Words: ecosystem service; long-term analysis; social-ecological thresholds; Spain; temporal dynamics

\section{INTRODUCTION}

Today's social and ecological rapid changes and unpredictability are prompting the development of new approaches to evaluate the relationships between people and nature (Leach et al. 2012, Chan et al. 2016). The social-ecological system (SES) framework enables the integration of data from diverse natural and social science disciplines and thus provides a theoretically grounded means of testing hypotheses about the dynamics and implications of social-ecological interactions (Folke et al. 2010). To this end, the SES framework highlights the importance of investigating the long-term relationships between people and nature (Berkes et al. 2003). This information is an essential part of understanding the complexity of SESs and identifying the root causes of environmental problems (Carpenter and Folke 2006, Olson et al. 2010).

The SES framework provides guidance on how to assess the social and ecological dimensions that contribute to sustainable resource use and management, but rarely if ever has it been operationalized at the national scale analyzing long-term social-ecological dynamics. Environmental governance is more effective when the scales of ecological processes are well matched with the human institutions charged with managing human-environment interactions (Leslie et al. 2015). Moreover, because previous longterm social-ecological analyses have largely focused on the local or global scale, these analyses have usually failed to include national scales (Scholes et al. 2013). For example, studies on the local scale have linked ecosystem services to human well-being (Iniesta-Arandia et al. 2014) and health (Olson et al. 2010), and studies at the global scale have explored links between ecosystem services and poverty alleviation (Fisher et al. 2014). However, because of the issue of context specificity, it is difficult to scale these studies up or down to policy-relevant national and regional scales (Selomane et al. 2015). Thus, there is a need for a comprehensive methodology that applies national-scale longterm indicators both to analyze how SESs evolve over time and to respond to different drivers of change and policy interventions (Butchart et al. 2010, Hauck et al. 2015).

We used the SES framework to assess the long-term socialecological changes and dynamics for Spain. Therefore, we have considered the entire nation-state of Spain as an SES. We define SES as a "bio-geo-physical" unit and its associated social actors and institutions. We focus on the national scale because SESs are complex and are delimited by spatial or functional boundaries that surround particular ecosystems and their problem context (Glaser et al. 2008). National scales are important in SES studies because national environmental policy regulates the entire "natural capital" that provides multiple services and on which the socioeconomic activities have an impact on human well-being.

Regarding environmental policies, the understanding of longterm social-ecological dynamics has also been emphasized. For example, the approval in 2011 of the Convention on Biological Diversity adopted a new strategic plan through 2020 that aims to stop biodiversity loss and ensure healthy ecosystems that provide people with essential ecosystem services (Maes et al. 2016). Previously, the Millennium Ecosystem Assessment (2005) introduced a new conceptual framework for analyzing social-

\footnotetext{
${ }^{1}$ Social-Ecological Systems Laboratory, Department of Ecology, Universidad Autónoma de Madrid, Madrid, Spain, ${ }^{2}$ Stockholm Resilience Centre, Stockholm University, Stockholm, Sweden, ${ }^{3}$ Agroecology, Food Sovereignty and Commons Research Group, University of Córdoba, ${ }^{4}$ FRACTAL Collective, Madrid, Spain, ${ }^{5}$ Department of Applied Research and Agricultural Extension, Madrid Institute for Rural, Agricultural and Food Research and Development (IMIDRA), Madrid, Spain, ${ }^{6}$ Departamento de Ecología, Universidad Autónoma de Madrid, Madrid, Spain, ${ }^{7}$ Chair in Agroecology and Food Systems, Universitat de Vic - Universitat Central de Catalunya (UVic-UCC), Vic, Spain, ${ }^{8}$ Group of Energy, Economy and Dynamic Systems, University of Valladolid, Valladolid, Spain, ${ }^{9}$ Institute for Ethics and Transdisciplinary Sustainability Research, Faculty of Sustainability, Leuphana University of Lüneburg, Lüneburg, Germany
} 
ecological dynamics and has had considerable influence in both the policy and scientific communities (Clark 2007). Corresponding to the adoption of this global assessment framework, some countries have conducted their own national ecosystem assessments (i.e., Biggs et al. 2004, Pereira et al. 2004, Japan Satoyama Satoumi Assessment 2010, UK National Ecosystem Assessment 2011, Spanish National Ecosystem Assessment 2013). However, most of the national ecosystem assessments have a critical gap: the lack of a temporal assessment that can reveal the evolution of social-ecological dynamics over time. Thus, a long-term social-ecological analysis using nationalscale indicators is needed to understand how past dynamics and changes can impact current conditions of ecosystems (Reyers et al. 2013, Ringold et al. 2013).

Although different approaches have been applied for modeling current interactions between SESs (Liu et al. 2007, Folke et al. 2011), the study of long-term dynamics in SESs remains poorly understood (Cundill and Fabricius 2009, Rocha et al. 2015). For example, abrupt and gradual changes are commonly found in SESs; however, there is a need for further analysis to identify social and ecological thresholds of change together (Dakos et al. 2015, Rocha et al. 2015). We define social-ecological thresholds as the simultaneous changes in socioeconomic and ecological processes that lead to a new social-ecological condition that defines a specific time period. Identifying these thresholds at the national scale can help us understand the evolution of the recent history of a country from a social-ecological perspective. The development of new analytical approaches to address these limitations is essential to support new environmental policies that will tackle future sustainability challenges.

We aimed to develop a methodological framework to understand long-term temporal social-ecological dynamics at the national scale. More specifically, the application of the framework to the case study of Spain allows a test of its usefulness in achieving the following objectives: (1) assessing the temporal relationships of various indicators in explaining social-ecological dynamics; (2) detecting social-ecological thresholds to identify those years for which there is a high probability of abrupt, simultaneous changes in social and ecological indicators; and (3) distinguishing the different social-ecological time periods and describing the last five decades in Spain from a social-ecological perspective.

\section{METHODS}

We designed a methodological framework comprising five steps to understand long-term social-ecological dynamics in Spain (Fig. 1).

\section{Step 1: adapting the driver-pressure-state-impact-response framework to understand social-ecological system dynamics}

We adopted the driver-pressure-state-impact-response (DPSIR) framework (European Environment Agency [EEA] 1999) with the SES lens to develop a more systems-based way of understanding long-term changes and dynamics. We selected the DPSIR framework because it provides an organized structure to analyze the causes, consequences, and responses to changes in ecosystems (Ness et al. 2010). In recent years, the DPSIR framework has evolved into an interdisciplinary tool for environmental analyses (EEA 1999). The framework is useful in that it provides a structure in which a number of physical, biological, chemical, and societal indicators can be analyzed to

set and evaluate targets and give a clear picture of progress or lack of progress in a number of policy areas (EEA 1999).

Fig. 1. Methodological process we developed to analyze socialecological dynamics using national indicators capable of capturing long-term changes. DPSIR, driver-pressure-stateimpact-response; SES, social-ecological system.

METHODOLOGICAL STEPS

Step 1. Adapting the DPSIR framework to SES

Step 2. Selecting the indicators under

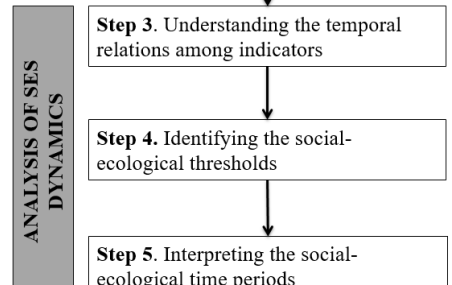
ecological time periods the DPSIR framework

METHODOLOGICAL OBJECTIVES

Adaptation of the DPSIR framework to understand social-ecological dynamics $\downarrow$ social-ecological dynamics

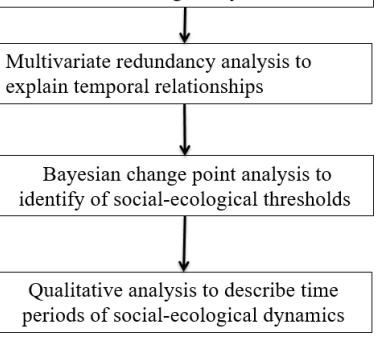

Recently, this conceptual framework has been proposed and used to assess ecosystem services (e.g., Grant et al. 2008, Rounsevell et al. 2010, Atkins et al. 2011, Kandziora et al. 2013, Santos-Martın et al. 2013, Cook et al. 2014, Pinto et al. 2014). We adopted this framework to specifically understand long-term social-ecological dynamics at the national scale. Within this framework, the dimension of "indirect drivers" includes the underlying factors promoting environmental change, such as demographic, economic, cultural, sociopolitical, and technological drivers (Millennium Ecosystem Assessment 2005). These indirect drivers produce various "direct drivers (pressures)," such as climate change, land-use change, pollution, alien species invasion, and overexploitation, which can directly affect the ecological integrity of ecosystems (Millennium Ecosystem Assessment 2005). These drivers of change in turn affect the "state" of ecosystems, which can be measured using different biodiversity indicators. The state of ecosystems has "impacts" on both the supply of ecosystem services and human well-being. Ecosystem services were classified as provisioning, regulating, and cultural services. Well-being was classified into material, e.g., domestic material consumption (DMC), and nonmaterial, e.g., health, dimensions (Millennium Ecosystem Assessment 2005). Finally, different "responses" promoted by governments and/or societies have the capability to control the effect of drivers or to preserve the ecosystem's capacity to supply services.

Although the methodological framework we use is an adaption of those provided by Santos-Martín et al. (2013), its originality lies in its temporal application to long-term social-ecological dynamics, which requires searching and using different indicators from those used by these authors. For more details about the methodological framework, see Santos-Martín et al. (2013).

\section{Step 2: selecting the indicators to operationalize the methodological framework}

A final set of 21 national indicators that are capable of explaining social-ecological dynamics was compiled for integration into the 
Table 1. Final set of 21 national indicators capable of explaining social-ecological dynamics in Spain. Indicators were adapted to the driver-pressure-state-impact-response (DPSIR) framework.

\begin{tabular}{|c|c|c|c|c|c|}
\hline \multicolumn{6}{|c|}{ Indicator Characteristics } \\
\hline \multicolumn{2}{|c|}{ DPSIR Dimension } & \multirow{2}{*}{$\begin{array}{l}\text { Relevant Attribute } \\
\text { Biodiversity }\end{array}$} & \multirow{2}{*}{$\begin{array}{l}\text { Indicator } \\
\text { Red List Index of fish, amphibians, reptiles, } \\
\text { mammals, and birds }\end{array}$} & \multirow{2}{*}{$\frac{\text { Description (Units) }}{\text { Dimensionless }}$} & \multirow{2}{*}{$\frac{\text { Time Horizon }}{1985-2000}$} \\
\hline State & Natural capital & & & & \\
\hline \multirow[t]{11}{*}{ Impacts } & $\begin{array}{l}\text { Provisioning } \\
\text { ecosystem services } \\
\text { (ESs) }\end{array}$ & Cultivated crops & Total production of cereals, fruits, and olive & Tons & $1961-2010$ \\
\hline & & Reared animals and their outputs & Total production of meat & Tons & $1961-2010$ \\
\hline & & Wild animals and their products & Beehives of Apis mellifera & Number of beehives & 1961-2008 \\
\hline & & Materials from plants for direct use & Total timber production & Millions of cubic meters & 1961-2009 \\
\hline & Regulating ESs & Maintenance of soil fertility & Fertilizer consumption & $\begin{array}{l}\text { Kilograms per hectare of } \\
\text { arable land }\end{array}$ & $1961-2007$ \\
\hline & & Natural hazard prevention & $\begin{array}{l}\text { Damages paid by insurance companies } \\
\text { because of floods }\end{array}$ & Number/year & $1971-2007$ \\
\hline & & Life cycle maintenance & Number of forest fires & Thousands/year & 1961-2008 \\
\hline & Cultural ESs & Recreation & Visitors to protected areas & Thousands/year & $1976-2009$ \\
\hline & & Local ecological knowledge & $\begin{array}{l}\text { Autochthonous sheep managed by } \\
\text { transhumant shepherds }\end{array}$ & Number of sheep & $1961-2009$ \\
\hline & Human well-being & Health dimension & Life expectancy at birth & Years & $1961-2010$ \\
\hline & & Material dimension & Domestic material consumption & Tons per inhabitant & $1961-2010$ \\
\hline Response & Policy & Declaration of protected areas & Protected areas declared & $\begin{array}{l}\text { Number of protected } \\
\text { areas }\end{array}$ & $1962-2010$ \\
\hline \multirow[t]{8}{*}{ Drivers } & Indirect & Economic & Gross domestic product (GDP) & $\begin{array}{l}\text { Millions of dollars per } \\
\text { capita (in international } \\
\text { dollars using purchasing } \\
\text { power parity) }\end{array}$ & 1961-2008 \\
\hline & & Demographic & Human population density & $\begin{array}{l}\text { Persons per square } \\
\text { kilometer }\end{array}$ & $1961-2010$ \\
\hline & & Scientific and technological & $\begin{array}{l}\text { Investment in research and development } \\
\text { programs }\end{array}$ & Percent of GDP & $1967-2009$ \\
\hline & Direct & Urban growth & Number of new houses & $\begin{array}{l}\text { Thousands of new } \\
\text { houses }\end{array}$ & 1970-2009 \\
\hline & & Invasive alien species & Number of invasive alien plants & $\begin{array}{l}\text { Number of invasive alien } \\
\text { plants }\end{array}$ & $1961-2005$ \\
\hline & & Overexploitation of biotic materials & Capture of Salmo salar in Spanish rivers & Tons & $1961-2005$ \\
\hline & & Overexploitation of abiotic materials & Groundwater extracted for irrigation & Hectometers & 1961-2004 \\
\hline & & Pollution & Total $\mathrm{CO}_{2}$ emissions & Millions of tons & $1961-2010$ \\
\hline
\end{tabular}

DPSIR framework (Table 1). To operationalize the framework, we initially identified those attributes that are associated with each dimension of the DPSIR framework. For each attribute, we selected those indicators that are scientifically credible and relevant for explaining social-ecological dynamics over time at the national scale (Heink et al. 2016). For inclusion, the indicators had to meet the following criteria: (1) indicators were clearly linked to DPSIR dimensions, e.g., endangered species express the "state" of biodiversity; (2) data were available through official statistical data sets; (3) data were quantifiable at the national scale; (4) data were scalable such that they could be aggregated into different scale levels; and (5) data were temporally explicit and available for at least 20 years within the time period 1960-2010 to allow trends to be measured over time. We selected 1960-2010 as the time period of analysis because the ecosystems and biodiversity of Spain underwent rapid and unprecedented changes during this period (Spanish National Ecosystem Assessment 2013). Selecting this time period also allowed us to balance the maximum number of years that explain Spain's recent social-ecological history with the availability of reliable data from official data sets in the analysis.

From an initial list of 53 indicators used in a previous study using national-scale indicators in Spain (Santos-Martín et al. 2013), a final set of 21 indicators was selected for analysis because the indicators met the inclusion criteria described previously (Table
1). Among the 21 indicators, 1 is related to the status of biodiversity; 9 are related to ecosystem services, i.e., 4 provisioning, 3 regulating, and 2 cultural services; 2 are related to human well-being; 1 is related to policy responses; 4 are related to indirect drivers of change; and 4 are related to direct drivers of change.

Step 3: understanding the temporal relations among indicators We performed a redundancy analysis (RDA) to determine patterns of the interactions between the indicators representing indirect and direct drivers of changes, as well as response options and the indicators representing the status of biodiversity, ecosystem services, and human well-being. To test the significance of the relationships between the abovementioned variables during the time period of $1960-2010$, we performed a Monte Carlo permutation test (1000 permutations). The Monte Carlo permutation test is used to evaluate whether the variation explained by the association between variables in the RDA axes is higher than would be explained by the same number of randomly generated variables. The RDA also allows researchers to obtain a simultaneous representation of the variables, as well as observations (in this research represented by years, from 1960 to 2010), in two or three dimensions, which is optimal for a covariance criterion (ter Braak 1992). The importance of different variables to the explanation of the temporal social-ecological patterns in Spain was assessed through their squared cosines on 
the respective axes. Additionally, we have represented each year (factor observations) individually to better observe changes in tendencies.

We conducted the RDA in XLSTAT (version 2009.6.02, Addinsoft). Prior to running the RDA, all variables were first normalized and standardized by subtracting the mean of the indicator value and dividing by the standard deviation. Normalization and standardization aim to remove the effects of scale and avoid biases as result of single variables dominating the model.

\section{Step 4: identifying the social-ecological thresholds}

We conducted a Bayesian change point (BCP) analysis (Barry and Hartigan 1993, Erdman and Emerson 2007) to estimate the probability of a change point occurring during each year from the two factors resulting from the RDA analysis. A change point can be defined as the date at which at least one parameter of a statistical model, e.g., mean, variance, intercept, and trend, undergoes an abrupt change (Seidou et al. 2007). The BCP model treats the change point in a time series as a parameter to be estimated. BCP analysis has been widely applied to regression models and is used to detect change points in time series (Beaulieu et al. 2012). For example, it has been applied in the earth sciences to detect change points, e.g., abrupt changes and regime shifts, and determine the timing of change (e.g., Beaulieu et al. 2012, Reid et al. 2016).

The BCP has been addressed in Bayesian statistics. The advantage of Bayesian statistics over classical statistics is the comprehensive description of parameters' uncertainty (Seidou et al. 2007). Although classical statistics may give the most probable position of the change point, Bayesian methods provide a full posterior probability distribution of its position. It thus provides much more information than a simple estimation and a credibility interval as usually obtained with classical methods. Another advantage is that Bayesian methods were applied considering single or multiple changes, in conjunction with a known or an unknown number of change points. We interpret the BCP by identifying change points (of maximum 5 years) with high probability ( 0.5 or higher) of observing abrupt changes in both factors. We assume that these change points represent a potential social-ecological threshold. These change points understood as social-ecological thresholds are then reinterpreted based on the RDA results (step 3) and used to identify distinct time periods (step 5).

\section{Step 5: identifying historical time periods and social-ecological dynamics}

Different periods were identified to describe Spain's socialecological dynamics over the last five decades in greater detail. We performed a qualitative analysis based on Holling's (2001) adaptive cycle metaphor to describe the different periods based on temporal relations among indicators. To do so, we used significant indicators of the accumulation and/or release of natural, human, or social capital, which enabled a description of the dynamics of the system and explained gradual and sudden changes that occurred during the identified periods. Although we acknowledge that the adaptive cycle metaphor has limitations, we agree with other authors (Allison and Hobbs 2004, González et al. 2008, Salvia and Quaranta 2015) that this metaphor is a useful communication tool for characterizing the social-ecological dynamics in each of the major periods that led to the current ecosystem conditions.

\section{RESULTS}

\section{Temporal relations among indicators}

The RDA results indicate a statistically significant association between the variables representing the state of biodiversity and some ecosystem services and those variables representing direct and indirect drivers and response options. The first 2 factors of the RDA accounted for $94.87 \%$ of the total variance of the 21 indicators used (Table 2). The biplot of the RDA, representing the first 2 axes, is shown in Figure 2. The positive scores of the first factor (F1; 81.08\% of the variance) were significantly associated with biodiversity loss; provisioning services, i.e., food from agriculture, livestock, or timber production; and cultural services, i.e., recreation (Fig. 2). The interaction between these variables over time was explained by land-use change as the main direct driver and economic development, measured by the gross domestic product (GDP), as the main indirect driver. The F1 also revealed an impact of these drivers on human well-being indicators, represented by life expectancy and DMC, thus showing how the socioeconomic development process has increased the level of human well-being, especially during the first decades of the period studied. As a result, the F1 was interpreted as the socioeconomic transformation that has occurred in Spain over the last 50 years.

Table 2. Results of the redundancy analysis (RDA) used to analyze the relationship between different indicators. Numbers represent standardized canonical coefficients of independent and dependent variables. Squared cosines were used to highlight in bold font those variables with higher significance for both factors. ES, ecosystem service; F1, factor 1 (socioeconomic); F2, factor two (ecological); HW, human well-being.

\begin{tabular}{llrr}
\hline \hline Variable Type & Information Type & F1 & F2 \\
\hline Dependent variables & & & \\
Red List Index & Biodiversity loss & $\mathbf{1 . 1 0 6}$ & $\mathbf{0 . 5 4 0}$ \\
Agriculture & ES (provisioning) & $\mathbf{1 . 2 8 5}$ & 0.118 \\
Livestock & ES (provisioning) & $\mathbf{1 . 3 9 6}$ & 0.018 \\
Wild animals and their products & ES (provisioning) & $\mathbf{1 . 4 0 7}$ & -0.080 \\
Timber & ES (provisioning) & $\mathbf{1 . 1 0 2}$ & $\mathbf{0 . 6 0 2}$ \\
Soil fertility & ES (regulating) & -0.951 & $\mathbf{- 0 . 8 1 4}$ \\
Water flow & ES (regulating) & $\mathbf{- 1 . 3 3 4}$ & 0.500 \\
Life cycle maintenance (fire control) & ES (regulating) & $\mathbf{- 1 . 1 5 0}$ & -0.364 \\
Local knowledge & ES (cultural) & $\mathbf{- 1 . 0 5 0}$ & $\mathbf{1 . 0 3 9}$ \\
Recreation & ES (cultural) & $\mathbf{1 . 3 3 6}$ & -0.579 \\
Life expectancy & HW (health) & $\mathbf{1 . 3 5 9}$ & 0.133 \\
Domestic material consumption & HW (material) & $\mathbf{1 . 3 6 4}$ & -0.122 \\
Independent variables & & & \\
Pollution & Direct driver & -0.478 & 0.057 \\
Overexploitation & Direct driver & 0.032 & -0.140 \\
Land-use change & Direct driver & $\mathbf{2 . 0 7 2}$ & $\mathbf{- 1 . 5 5 0}$ \\
Invasive alien species & Direct driver & 1.708 & $\mathbf{3 . 2 6 4}$ \\
Population density & Indirect driver & -0.669 & -0.687 \\
Gross domestic product & Indirect driver & $\mathbf{1 . 5 9 5}$ & -1.123 \\
Urban population & Indirect driver & -0.111 & 0.241 \\
Science and technology & Indirect driver & -0.580 & 0.779 \\
Protected areas & Response & -0.570 & -1.034 \\
Results of the RDA & & & \\
Eigenvalue & & 9.403 & 1.599 \\
Variance (\%) & & 81.084 & 13.790 \\
Variance accumulated (\%) & & 81.084 & 94.874 \\
\hline & & &
\end{tabular}


Fig. 2. Scatterplot representing factor scores from the redundancy analysis. Indicators highlighted in bold font represent those variables with a higher importance in explaining temporal social-ecological (SE) trends.

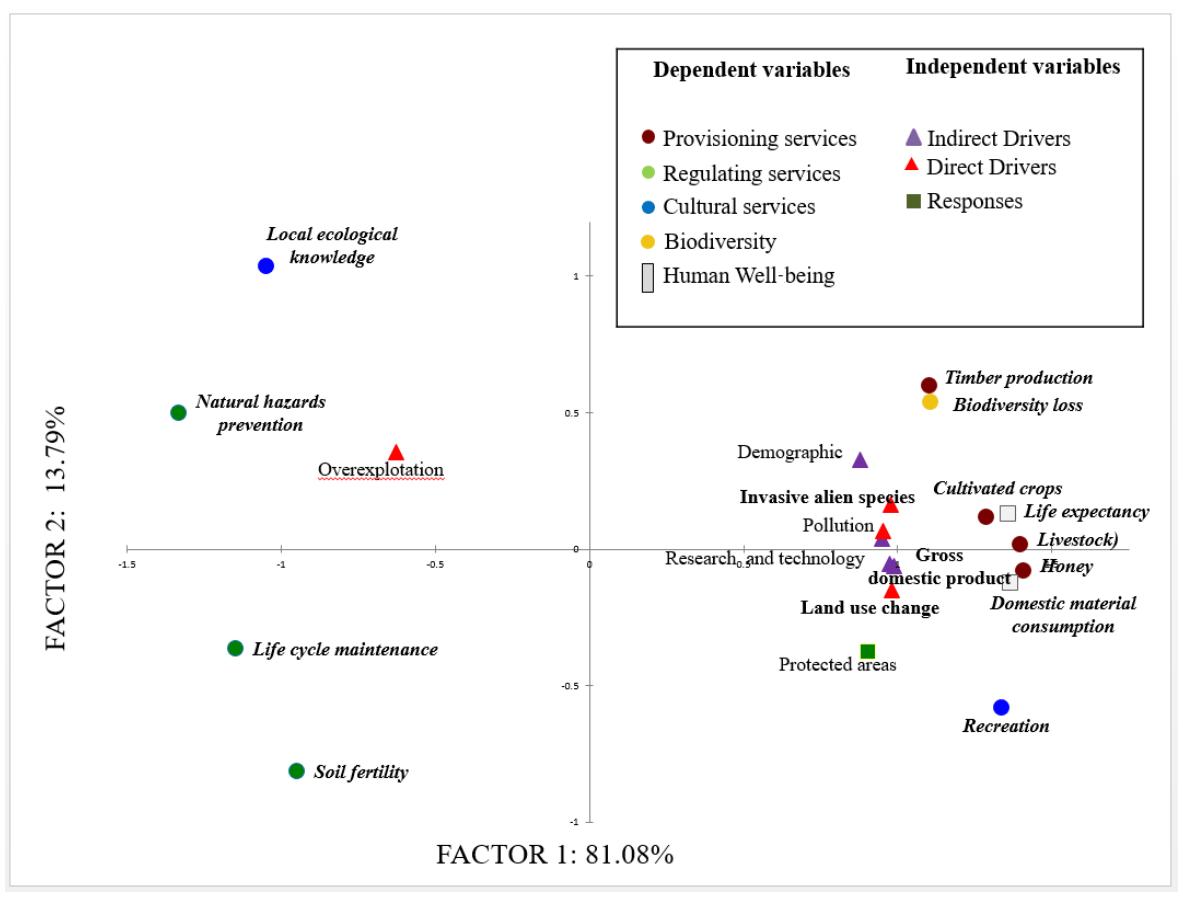

Although the second factor (F2) only accounts for $13.79 \%$ of the total variance (Table 2), it describes a second relevant trend of relationships between social-ecological indicators. Indeed, the positive scores of the F2 revealed the associations among biodiversity loss; cultural ecosystem services, i.e., local ecological knowledge; regulating services, i.e., water flow; and provisioning, i.e., timber production, all of which are influenced by direct drivers, such as the overexploitation of abiotic materials, i.e., groundwater, and indirect drivers, i.e., urban population density. In the negative scores, we found that regulating services, i.e., soil fertility and life cycle maintenance of forest fires, and cultural services associated with urban population, i.e., recreation, were related to the response option, i.e., creation of natural protected areas (Fig. 2). Therefore, the F2 was explained by changes in the structure and functions at an ecological level that have occurred in Spanish ecosystems because of the abandonment of rural areas and assumption of an urban lifestyle (Fig. 2).

\section{Identification of social-ecological thresholds}

Based on our interpretation of the BCA results, we identified 4 social-ecological thresholds at which the trajectory of indicators showed a high probability ( 0.5 or higher) of abrupt changes in both factors (Fig. 3). The historical time periods associated with those thresholds are presented in a scatterplot diagram (Fig. 4), which uses different colors to indicate each time period, and the distance between each year can be interpreted as a sign of the change rate of social-ecological indicators over time. If the distance between points increases, it indicates that the rate of change has increased for those years.
Fig. 3. Results from the Bayesian change point analysis estimating the probability of a social-ecological (SE) threshold occurring in each year from the two factors resulting from the redundancy analysis analysis: factor 1, social; factor 2 , ecological.

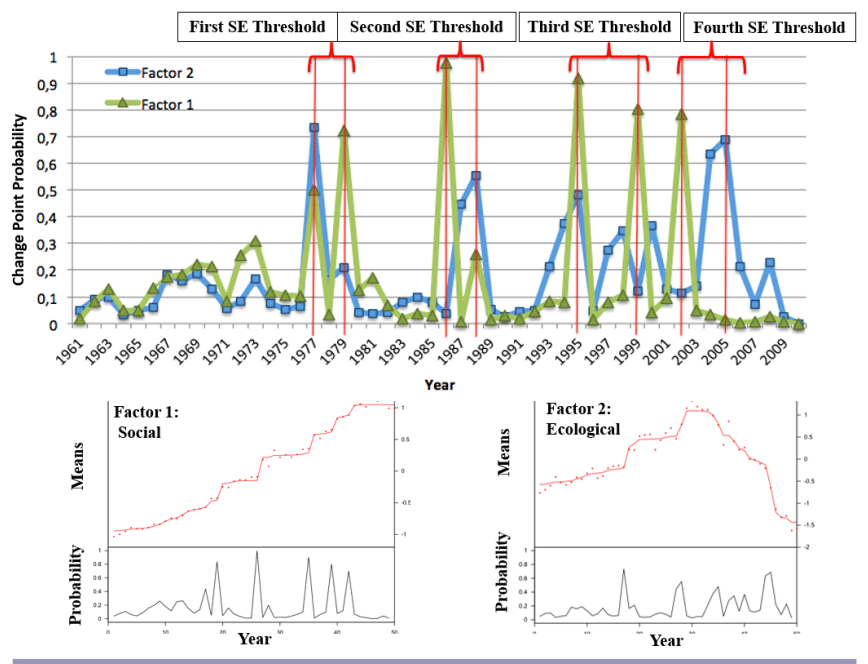

Specifically, our results show that there is a high change point probability in the ecological component (F2) in 1977 and in the socioeconomic component (F1) in 1979, which suggests that the first social-ecological threshold is during the 1977-1979 period (Figs. 3 and 4). This threshold fits well with the strong transition 
after the end of the dictatorship, representing a new socialecological period that can be identified as the end of traditional agricultural society. The second identified social-ecological threshold (1986-1988) occurred when Spain's accession to the European Union (EU) occurred. This change point is characterized by deep structural changes that bring a high probability of both socioeconomic (1986, in F1) and ecological (1989, in F2) change. The third social-ecological threshold (1995-1999) is characterized by the great economic growth of urban society (1995, in F1) and its simultaneous impact on the ecological component (1995, in F2), which is followed by an additional economic shift in 1999 (Figs. 3 and 4). Finally, we observe a fourth social-ecological threshold in 2003-2005, which is characterized in 2003 by the transition from an economic bubble to the first signal of the economic crisis and in 2005 by a shift in the impact on the ecological components.

Fig. 4. Scatterplot combining the results of the redundancy snalysis and Bayesian change point analysis to represent the social-ecological thresholds and time periods. The diagram shows how the study years (1961-2010) follow a nonlinear dynamic and where there is a high probability of socialecological (SE) thresholds of change in Spain. Each color represents a time period identified.

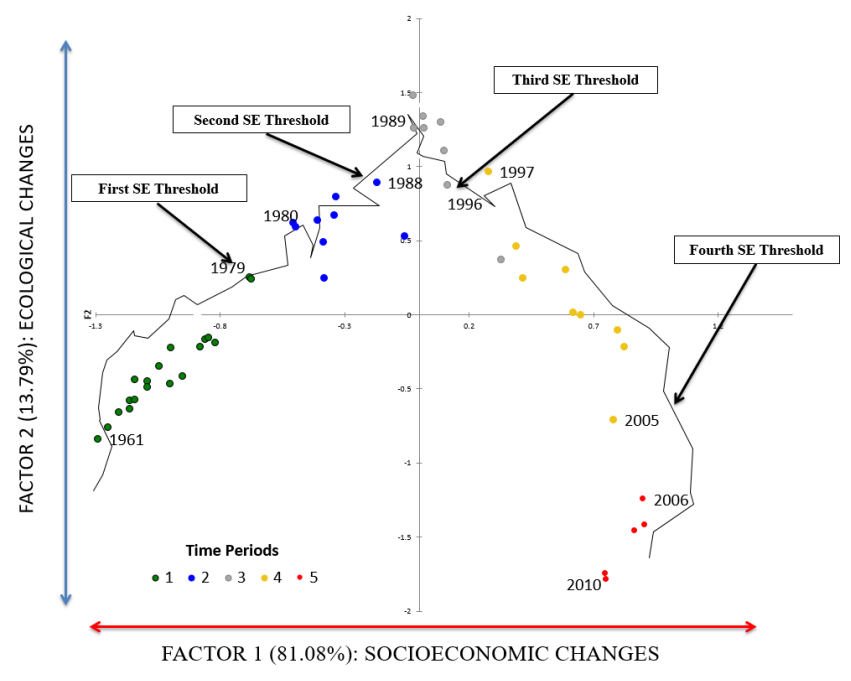

As shown in the fourth identified period, the frequency of probable thresholds related to both socioeconomic (F1) and ecological (F2) changes of the system increased (Fig. 4). This suggests that the last two decades under study have had higher change rates of social-ecological indicators, i.e., that Spain is undergoing an acceleration process similar to that occurring at the global level.

\section{Description of social-ecological time periods}

We used Holling's adaptive cycle metaphor to designate and describe five different periods that can explain the primary socialecological thresholds. We adapted the classic heuristic model, which consists of four sequential stages that reflect the cyclic processes of growth, conservation, release, and reorganization that are experienced by most SESs. We fit the five identified socialecological periods into one complete cycle of renewal (Fig. 5).
The main social-ecological characteristics of each period and their relation to the accumulation or release of natural, social, and human capital are described subsequently (refer to Appendix 1 for a better understanding of the time evolution of individual indicators).

Fig. 5. Adaptation of the time periods identified from the social-ecological dynamics using the adaptive cycle. The main social-ecological characteristics of each period and their relation to the accumulation or release of natural, social, and human capital are described in relation to selected indicators.

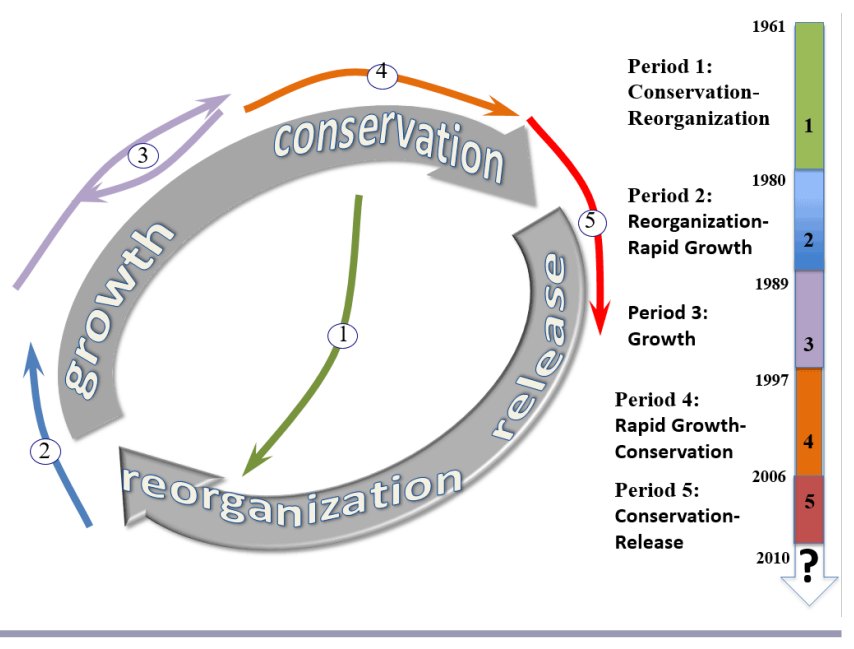

Conservation-reorganization phase: 1961-1979

From dictatorship to democracy: This period corresponds to a forward loop of the adaptive cycle and is characterized by the rapid 1978 transition from a dictatorship to a new democratic political system. The end of the dictatorship was characterized by the accumulation of social, financial, and physical capital associated with accelerated economic growth and consumption in the new urban society. Simultaneously, the social and institutional structures associated with the dictatorship regime became very rigid. The end of this cycle was associated with the rapid transition of social and institutional structures that were associated with the 1975 abolition of the dictatorship. The transition was planned as a smooth process, avoiding the collapse of the system, and rapidly led to a renewal phase in a new democratic regime (Fig. 5). Spain shifted from a traditional, local, low-consumption, and slow lifestyle based on the agrarian sector to a "modern" society with acceleration in lifestyles and the rate of consumption.

\section{Reorganization-rapid growth phase: 1980-1988}

European adhesion: During this period, most of the structural changes that consolidated the maintenance and proliferation of the new organizational system in Spanish society occurred, i.e., a systematic process of economic liberalization, industrial restructuring, and reform of formal institutions took place. New emergent opportunities and innovations characterize this period of rapid growth in the country's social-ecological dynamics (Fig. 5). After Spain's accession to the European Economic Community, which was formalized in 1985, Spain experienced a period of economic growth, which for five consecutive years 
achieved the Community's highest growth rate and promoted a first wave of house construction coupled with a rise in employment. The consolidation of urban society resulted in a way of life that was increasingly disconnected from agricultural systems. This caused drastic changes in the rural lifestyle, i.e., farm closures and quota-driven production levels, associated with traditional primary economic activities and had important consequences, such as decreasing biodiversity and some regulating services, i.e., soil fertility; provisioning services, i.e., timber production; and cultural services, i.e., local ecological knowledge.

\section{Growth reversal phase: 1989-1996}

The urban society and the first recession: The concentration of the population in large urban and coastal areas was especially evident in Spain during this period, with $80 \%$ of the population living in municipalities of more than 10,000 inhabitants. The economic growth associated with EU support for infrastructure and the Common Agricultural Policy consolidated during this period. However, this long period of growth shifted in 1993 with the first economic recession that hit Spain after the 1992 euphoria of the Expo and Olympic Games. The effects of the crisis included an increase in the unemployment rate to $24 \%$, which was linked to the end of industrial restructuring. The effects worsened, especially in the agrarian sector, i.e., traditional models such as livestock transhumance experienced a sharp decline, and social conflict associated with water stress caused by an important drought reached its peak in 1995. Taken together, this situation leads to the conclusion that losses in agricultural and industrial production, coupled with the increased outsourcing of the economy, make Spain's trajectory especially vulnerable to global crises.

\section{Rapid growth to conservation phase: 1997-2005}

The great economic bubble: The end of the first recession, which prevented the system from entering a release phase, ceased, and the conservation phase began. The conservation phase was associated with the most intensive GDP growth of the studied lapse (Fig. 5). This huge expansion of the Spanish economy was based on the accumulation of physical and financial capital, mostly associated with a development trajectory based on increased infrastructure and housing construction, i.e., housing property bubble, linked to a liberalization of land laws and the abundant and cheap liquidity that Spanish banks received from international financial institutions. The 1999 shift was influenced both by the adoption of the euro as the new currency and by the intensification of urban sprawl with the 1998 change in the Spanish Land Law. As a direct consequence, during this period $\mathrm{CO}_{2}$ emissions grew from 250 to $350 \mathrm{ppm}$ each year. Cultural ecosystem services linked to an urban lifestyle, such as recreation, tourism, or education, grew, whereas cultural rural services linked to tradition, culture, and a sense of attachment decreased rapidly, as did important regulating services, i.e., soil fertility and water regulation.

\section{Conservation-release phase: 2006-2010}

The bubble burst: The collapse phase that marks the beginning of a back loop is characterized by a rapid loss of financial, social, and human capital (Fig. 5). When Western economic prosperity broke down in 2008, unsustainable private debt provoked a European sovereign debt crisis that primarily affected the southern European states. The crash provoked the emergence of social movements against governmental policies to prevent financial bankruptcy. The influence of both direct and indirect drivers decreased during this period, especially with respect to drivers related to land-use changes for urbanization. This declining trend in socioeconomic indicators had a direct impact on ecological variables such as reduced atmospheric emissions and decreased forest fires.

\section{DISCUSSION}

\section{Developing a framework for conceptualizing social-ecological systems at the national scale}

Social-ecological research has become very popular in the fields of environmental science and policy (Carpenter and Folke 2006), and it can be used to frame multiple environmental policy targets (Hauck et al. 2015). The attractiveness of the approach relies on its integrative character, which allows interrelating ecological and social variables (Walker et al. 2004). Moreover, social-ecological research can identify options for recoupling social and ecological subsystems both at the practitioner and policy levels by identifying the relevant social-ecological characteristics to manage.

We presented and tested an approach with the aim to develop a more systems-based way of understanding long-term socialecological temporal dynamics at the national level. Therefore, the two main strengths of our study are that it (1) develops and tests a framework for conceptualizing SESs and (2) demonstrates a method for identifying and evaluating thresholds and regime shifts in long-term social-ecological analysis. Long-term temporal dynamics are an important component of the SES approach because responses are often subject to time lags (Dawson et al. 2010). The methodological approach we have represented can promote insight into the properties of SESs and thus aid understanding to tackle future sustainability challenges. It has a number of advantages over previous analyses of past long-term social-ecological dynamics. First among these is that it is explicit in identifying social-ecological thresholds as a key element to describe the complex transformations of socialecological dynamics. This is an important contribution because, to our knowledge, no previous long-term analysis has used components of ecological and social systems simultaneously to identify social-ecological thresholds. The interpretation of socialecological threshold that we have proposed is very flexible and can be applied to a wide range of SES studies.

Second, the proposed approach also makes explicit the importance of the national scale to understand long-term temporal dynamics of the SES method. This recognition of an entire nation as an SES can help to reinterpret national-level ecosystem indicators through a new conceptual lens to develop a more systems-based way of understanding long-term changes and dynamics. For example, the European Commission emphasizes the importance of mapping and assessing ecosystem service information at the national level as a basis of implementation of the EU Biodiversity Strategy for 2020 (European Commission 2011).

In addition, the approach we have used, at the national scale, could be applied to other countries and regions. However, we acknowledge that an important limitation is that this approach 
does not allow the exploration of associations across different scales. Thus, an improvement of the proposed approach is needed to better understand SES dynamics among regions and the relationships between national and global systems, which ultimately might facilitate better understanding of long-term sustainable conservation strategies (Rounsevell et al. 2010). Further research challenges include understanding trade-offs within a temporal context to compare temporal trends, the application of new methods to better examine spatially explicit variations, and the exploration of lag times between social and ecological thresholds that are coupled (Mouchet et al. 2014). This situation presents opportunities with which new conservation strategies should be managed in coordination with policies in other sectors at different organizational scales to manage the effects of direct drivers on biodiversity loss. Furthermore, the proposed approach opens the door for future studies that aim to further understand SES dynamics at different scales.

The proposed approach has, however, other limitations. It certainly needs more comprehensive testing against a wider range of real-world examples, which would help in refining the methodological approach and its practical application. Furthermore, the approach does not include a full set of nationalscale indicators to describe in detail the long-term ecological and social dynamics. Although the use of only 21 national-scale, social-ecological indicators from a larger list involved the loss of some information, limiting the generalizability of our conclusions, it also facilitated a rigorous process in data acquisition, being sure that the information selected was officially available for the 50-year timescale under investigation.

The proposed approach can be seen as a starting point in applying the concept of social-ecological thresholds. Moreover, it is important to note that the proposed approach does not substitute for other frameworks for long-term SES analysis but complements them through acknowledgement and identification of the inclusion of social-ecological threshold as a key element to describe the complex transformations of social-ecological dynamics.

\section{Testing the approach for assessing social-ecological temporal dynamics in Spain}

Our results suggest that social-ecological factors are a major force in shaping ecosystems over time. For example, in the last 50 years, Spain's biodiversity and ecosystem services have undergone rapid and unprecedented degradation because of the unsustainability of the country's prevailing socioeconomic development trajectory and the lifestyle associated with it (Spanish National Ecosystem Assessment 2013). Many social characteristics, such as ruralurban migration and the abandonment of traditional practices and landscapes, have affected these historical dynamics in ecosystems (Mulligan et al. 2004). The trends of the selected indicators we found reveal that since 2006, there have been declining variations in the drivers of change, clearly showing that the current socioeconomic crisis has had some positive effects on ecological indicators in Spain. This result supports the idea that the underlying causes of ecosystem degradation are mainly social circumstances.

Some studies, such as the Spanish National Ecosystem Assessment (Spanish National Ecosystem Assessment 2013), have concluded that Spain still has sufficient critical natural capital to provide this and future generations with a positive environment to maintain human well-being. However, unless we take urgent steps to halt and reverse the degradation of certain ecosystem services and the loss of biodiversity, we might approach a new threshold of change that, once exceeded, might bring us into an unpredictable and undesirable situation of socialecological unsustainability and the deterioration of human wellbeing (Nelson et al. 2006). Our results support this idea by showing that after crossing certain social-ecological thresholds, some dimensions of human well-being, such as health, are negatively affected by the progressive degradation of regulating services, i.e., water flow and soil fertility, and biodiversity loss.

Therefore, it is necessary to adopt structural measures to build a new governance framework that modulates the interactions between human society and ecosystems and to redefine a new sustainable trajectory (Martín-Lopez and Montes 2015). There is evidence that ecosystems might need to maintain baseline levels, e.g., in terms of the abundance and diversity of species, to function effectively and deliver many important ecosystem services (Rounsevell et al. 2010). Below critical thresholds, ecosystems might reach a new change point and suddenly switch in character, no longer providing the same kind or level of ecosystem services. Some studies even suggest that a planetary-scale tipping point, i. e., radical changes in the global ecosystem as a whole, might be approaching (Barnosky et al. 2012).

Based on our results, we believe that the current socioeconomic crisis is paradoxically a "window of opportunity" in which our development trajectory could begin a genuine ecological transition (Olsson et al. 2006, Chaffin and Gunderson 2016). It is critical to promote a new reorganizational phase in which processes of creation, innovation, and experimentation are undertaken to support the sustainable management of ecosystems and foster the skills of individuals, society, and institutions, thus creating a new organizational social-ecological system.

\section{CONCLUSION}

We presented a comprehensive methodological framework to understand long-term social-ecological thresholds and dynamics at the national scale. In particular, we tested this approach to understand how Spain has changed in the last five decades from a social-ecological perspective. Results synthesize and visualize long-term social-ecological dynamics and thus make it more accessible for researchers, decision makers, and anyone interested in the social-ecological perspective at the national level. However, we acknowledge that an important limitation is that this approach does not allow the exploration of associations across different scales. Thus, future research is needed to better understand socialecological dynamics at the appropriate scale, e.g., global and subnational, at which to deploy new conservation strategies, which ultimately might facilitate a genuine ecological transition.

Responses to this article can be read online at: http://www.ecologyandsociety.org/issues/responses. php/10734 


\section{Acknowledgments:}

This study was designed as part of the Spanish National Ecosystem Assessment (http://www.ecomilenio.es/). All of the research members of the Spanish Ecosystem Assessment and SocialEcological Systems Laboratory (http://www. laboratoriosocioecosistemas. esl) from the Autonomous University of Madrid provided ideas that inspired this study. This work was supported by the Biodiversity Foundation (http://www.fundacion-biodiversidad.es/) of the Spanish Ministry of Agriculture, Food and Environment. Partial financial support was also provided by the Ministry of Economy and Competitiveness of Spain (project CGL2014-53782-P: ECOGRADIENTES). The Spanish National Institute for Agriculture and Food Research and Technology (INIA) funded Marina Garcia-Llorente as part of the European Social Fund. Blanca González Garcia-Mon participated in this article as a "la Caixa" Banking Foundation scholar. The funders had no role in the study design, data collection and analysis, preparation of the report, or the decision to submit the study for publication.

\section{LITERATURE CITED}

Allison, H. E., and R. J. Hobbs. 2004. Resilience, adaptive capacity, and the "Lock-in Trap" of the Western Australian agricultural region. Ecology and Society 9(1):3. https://doi. org/10.5751/ES-00641-090103

Atkins, J. P., D. Burdon, M. Elliott, and A. J. Gregory. 2011. Management of the marine environment: integrating ecosystem services and societal benefits with the DPSIR framework in a systems approach. Marine Pollution Bulletin 62:215-226. https:// doi.org/10.1016/j.marpolbul.2010.12.012

Barnosky, A. D., E. A. Hadly, J. Bascompte, E. L. Berlow, J. H. Brown, M. Fortelius, W. M. Getz, J. Harte, A. Hastings, P. A. Marquet, N. D. Martinez, A. Mooers, P. Roopnarine, G. Vermeij, J. W. Williams, R. Gillespie, J. Kitzes, C. Marshall, N. Matzke, D. P. Mindell, E. Revilla, and A. B. Smith. 2012. Approaching a state shift in Earth's biosphere. Nature 486:52-58. https://doi. org/10.1038/nature11018

Barry, D., and J. A. Hartigan. 1993. A Bayesian analysis for change point problems. Journal of the American Statistical Association 88:309-319. https://doi.org/10.2307/2290726

Beaulieu, C., J. Chen, and J. L. Sarmiento. 2012. Change-point analysis as a tool to detect abrupt climate variations. Philosophical Transactions of the Royal Society A: Mathematical, Physical and Engineering Sciences 370:1228-1249. https://doi.org/10.1098/ rsta.2011.0383

Berkes, F., J. Colding, and C. Folke. 2003. Navigating socialecological systems: building resilience for complexity and change. Cambridge University Press, Cambridge, UK. https://doi. org/10.1017/CBO9780511541957

Biggs, R., E. Bohensky, P. V. Desanker, C. Fabricius, T. Lynam, A. A. Misselhorn, C. Musvoto, M. Mutale, B. Reyers, R. J. Scholes, S. Shikongo, and A. S. van Jaarsveld. 2004. Nature supporting people: the Southern African Millennium Ecosystem Assessment. Council for Scientific and Industrial Research, Pretoria, South Africa.
Butchart, S. H., M. Walpole, B. Collen, A. van Strien, J. P. W. Scharlemann, R. E. A. Almond, J. E. M. Baillie, B. Bomhard, C. Brown, J. Bruno, K. E. Carpenter, G. M. Carr, J. Chanson, A. M. Chenery, J. Csirke, N. C. Davidson, F. Dentener, M. Foster, A. Galli, J. N. Galloway, P. Genovesi, R. D. Gregory, M. Hockings, V. Kapos, J.-F. Lamarque, F. Leverington, J. Loh, M. A. McGeoch, L. McRae, A. Minasyan, M. Hernández Morcillo, T. E. E. Oldfield, D. Pauly, S. Quader, C. Revenga, J. R. Sauer, B. Skolnik, D. Spear, D. Stanwell-Smith, S. N. Stuart, A. Symes, M. Tierney, T. D. Tyrrell, J.-C. Vié, and R. Watson. 2010. Global biodiversity: indicators of recent declines. Science 328:1164-1168. https://doi.org/10.1126/science.1187512

Carpenter, S. R., and C. Folke. 2006. Ecology for transformation. Trends in Ecology and Evolution 21:309-315. https://doi. org/10.1016/j.tree.2006.02.007

Chaffin, B. C., and L. H. Gunderson. 2016. Emergence, institutionalization and renewal: rhythms of adaptive governance in complex social-ecological systems. Journal of Environmental Management 165:81-87. https://doi.org/10.1016/j.jenvman.2015.09.003

Chan, K. M. A., P. Balvanera, K. Benessaiah, M. Chapman, S. Díaz, E. Gómez-Baggethun, R. Gould, N. Hannahs, K. Jax, S. Klain, G. W. Luck, B. Martín-López, B. Muraca, B. Norton, K. Ott, U. Pascual, T. Satterfield, M. Tadaki, J. Taggart, and N. Turner. 2016. Opinion: why protect nature? Rethinking values and the environment. Proceedings of the National Academy of Sciences of the United States of America 113:1462-1465. https:// doi.org/10.1073/pnas. 1525002113

Clark, W. C. 2007. Sustainability science: a room of its own. Proceedings of the National Academy of Sciences of the United States of America 104:1737-1738. https://doi.org/10.1073/ pnas.0611291104

Cook, G. S., P. J. Fletcher, and C. R. Kelble. 2014. Towards marine ecosystem based management in South Florida: investigating the connections among ecosystem pressures, states, and services in a complex coastal system. Ecological Indicators 44:26-39. https:// doi.org/10.1016/j.ecolind.2013.10.026

Cundill, G., and C. Fabricius. 2009. Monitoring in adaptive comanagement: toward a learning based approach. Journal of Environmental Management 90:3205-3211. https://doi.org/10.1016/ j.jenvman.2009.05.012

Dakos, V., S. R. Carpenter, E. H. van Nes, and M. Scheffer. 2015. Resilience indicators: prospects and limitations for early warnings of regime shifts. Philosophical Transactions of the Royal Society B: Biological Sciences 370:20130263. https://doi.org/10.1098/ $\underline{\text { rstb. } 2013.0263}$

Dawson, T. P., M. D. A. Rounsevell, T. Kluvánková-Oravská, V. Chobotová, and A. Stirling. 2010. Dynamic properties of complex adaptive ecosystems: implications for the sustainability of service provision. Biodiversity and Conservation 19:2843-2853. https://doi.org/10.1007/s10531-010-9892-Z

Erdman, C., and J. W. Emerson. 2007. bcp: an R package for performing a Bayesian analysis of change point problems. Journal of Statistical Software 23:1-13. https://doi.org/10.18637/jss.v023. $\underline{\mathrm{i} 03}$ 
European Commission. 2011. Communication from the Commission to the European Parliament, the Council, the Economic and Social Committee and the Committee of the Regions. Brussels, 3.5.2011 COM(2011) 244 final. European Commission, Brussels, Belgium.

European Environment Agency (EEA). 1999. Environmental indicators: typology and overview. Technical Report No. 25. EEA, Copenhagen, Denmark.

Fisher, J. A., G. Patenaude, K. Giri, K. Lewis, P. Meir, P. Pinho, M. D. A. Rounsevell, and M. Williams. 2014. Understanding the relationships between ecosystem services and poverty alleviation: a conceptual framework. Ecosystem Services 7:34-45. https://doi. org/10.1016/j.ecoser.2013.08.002

Folke, C., S. R. Carpenter, B. Walker, M. Scheffer, T. Chapin, and J. Rockström. 2010. Resilience thinking: integrating resilience, adaptability and transformability. Ecology and Society 15(4):20. https://doi.org/10.5751/ES-03610-150420

Folke, C., A. Jansson, J. Rockström, P. Olsson, S. R. Carpenter, F. S. Chapin III, A.-S. Crépin, G. Daily, K. Danell, J. Ebbesson, T. Elmqvist, V. Galaz, F. Moberg, M. Nilsson, H. Österblom, E. Ostrom, Å. Persson, G. Peterson, S. Polasky, W. Steffen, B. Walker, and F. Westley. 2011. Reconnecting to the biosphere. AMBIO 40:719. https://doi.org/10.1007/s13280-011-0184-y

Glaser, M., G. Krause, B. Ratter, and M. Welp. 2008. Human/ nature interaction in the Anthropocene: potentials of socialecological systems analysis. GAIA: Ecological Perspective for Science and Society 17:77-80. https://doi.org/10.4324/9780203123195

González, J., C. Montes, J. Rodríguez, and W. Tapia. 2008. Rethinking the Galapagos Islands as a complex social-ecological system: implications for conservation and management. Ecology and Society 13(2):13. https://doi.org/10.5751/ES-02557-130213

Grant, F., J. Young, P. Harrison, M. Sykes, M. Skourtos, M. Rounsevell, T. Kluvankova Oravska, J. Settele, M. Musche, C. Anton, and A. Watt. 2008. Ecosystem services and drivers of biodiversity change. Report of the RUBICODE e-conference, April 2008. Natural Environment Research Council/Centre for Ecology and Hydrology, Penicuik, UK.

Hauck, J., K. L. Winkler, and J. A. Priess. 2015. Reviewing drivers of ecosystem change as input for environmental and ecosystem services modelling. Sustainability of Water Quality and Ecology 5:9-30. https://doi.org/10.1016/j.swaqe.2015.01.003

Heink, U., J. Hauck, K. Jax, and U. Sukopp. 2016. Requirements for the selection of ecosystem service indicators - the case of MAES indicators. Ecological Indicators 61:18-26. https://doi. org/10.1016/j.ecolind.2015.09.031

Holling, C. S. 2001. Understanding the complexity of economic, ecological, and social systems. Ecosystems 4:390-405. https://doi. org/10.1007/s10021-001-0101-5

Iniesta-Arandia, I., M. García-Llorente, P. A. Aguilera, C. Montes, and B. Martín-López. 2014. Socio-cultural valuation of ecosystem services: uncovering the links between values, drivers of change, and human well-being. Ecological Economics 108:36-48. https://doi.org/10.1016/j.ecolecon.2014.09.028
Japan Satoyama Satoumi Assessment. 2010. Satoyama-Satoumi ecosystems and human well-being: socio-ecological production landscapes of Japan - summary for decision makers. United Nations University, Tokyo, Japan.

Kandziora, M., B. Burkhard, and F. Müller. 2013. Interactions of ecosystem properties, ecosystem integrity and ecosystem service indicators - a theoretical matrix exercise. Ecological Indicators 28:54-78. https://doi.org/10.1016/j.ecolind.2012.09.006

Leach, M., J. Rockström, P. Raskin, I. Scoones, A. C. Stirling, A. Smith, J. Thompson, E. Millstone, A. Ely, E. Arond, C. Folke, and P. Olsson. 2012. Transforming innovation for sustainability. Ecology and Society 17(2):11. https://doi.org/10.5751/ES-04933-170211

Leslie, H. M., X. Basurto, M. Nenadovic, L. Sievanen, K. C. Cavanaugh, J. J. Cota-Nieto, B. E. Erisman, E. Finkbeiner, G. Hinojosa-Arango, M. Moreno-Báez, S. Nagavarapu, S. M. W. Reddy, A. Sánchez-Rodríguez, K. Siegel, J. J. UlibarriaValenzuela, A. Hudson Weaver, and O. Aburto-Oropeza. 2015. Operationalizing the social-ecological systems framework to assess sustainability. Proceedings of the National Academy of Sciences of the United States of America 112(19):5979-5984. https://doi.org/10.1073/pnas. 1414640112

Liu, J., T. Dietz, S. R. Carpenter, C. Folke, M. Alberti, C. L. Redman, S. H. Schneider, E. Ostrom, A. N. Pell, J. Lubchenco, W. Taylor, Z. Ouyang, P. Deadman, T. Kratz, and W. Provencher. 2007. Coupled human and natural systems. AMBIO 36:639-649. https://doi.org/10.1579/0044-7447(2007)36[639:CHANS]2.0.CO;2

Maes, J., C. Liquete, A. Teller, M. Erhard, M. L. Paracchini, J. I. Barredo, B. Grizzetti, A. Cardoso, F. Somma, J.-E. Petersen, A. Meiner, E. R. Gelabert, N. Zal, P. Kristensen, A. Bastrup-Birk, K. Biala, C. Piroddi, B. Egoh, P. Degeorges, C. Fiorina, F. SantosMartín, V. Naruševičius, J. Verboven, H. M. Pereira, J. Bengtsson, K. Gocheva, C. Marta-Pedroso, T. Snäll, C. Estreguil, J. SanMiguel-Ayanz, M. Pérez-Soba, A. Grêt-Regamey, A. I. Lillebø, D. A. Malak, S. Condé, J. Moen, B. Czúcz, E. G. Drakou, G. Zulian, and C. Lavalle. 2016. An indicator framework for assessing ecosystem services in support of the EU Biodiversity Strategy to 2020. Ecosystem Services 17:14-23. https://doi. org/10.1016/j.ecoser.2015.10.023

Martín-López, B., and C. Montes. 2015. Restoring the human capacity for conserving biodiversity - a social-ecological approach. Sustainability Science 10:699-706. https://doi. org/10.1007/s11625-014-0283-3

Millennium Ecosystem Assessment. 2005. Ecosystems and human well-being: synthesis. Island, Washington, D.C., USA.

Mouchet, M. A., P. Lamarque, B. Martín-López, E. Crouzat, P. Gos, C. Byczek, and S. Lavorel. 2014. An interdisciplinary methodological guide for quantifying associations between ecosystem services. Global Environmental Change 28:298-308. https://doi.org/10.1016/j.gloenvcha.2014.07.012

Mulligan, M., S. M. Burke, and M. C. Ramos. 2004. Climate change, land-use change and the "desertification" of Mediterranean Europe. Pages 257-279 in S. Mazzoleni, G. Di Pasquale, M. Mulligan, P. Di Martino, and F. Rego, editors. Recent dynamics of the Mediterranean vegetation and landscape. Wiley, Chichester, West Sussex, UK. https://doi.org/10.1002/0470093714. $\underline{\operatorname{ch} 22}$ 
Nelson, G.C., E. Bennett, A. A. Berhe, K. Cassman, R. DeFries, T. Dietz, A. Dobermann, A. Dobson, A. Janetos, M. Levy, D. Marco, N. Nakicenovic, B. O’Neill, R. Norgaard, G. PetschelHeld, D. Ojima, P. Pingali, R. Watson, and M. Zurek. 2006. Anthropogenic drivers of ecosystem change: an overview. Ecology and Society 11(2):29. https://doi.org/10.5751/ES-01826-110229

Ness, B., S. Anderberg, and L. Olsson. 2010. Structuring problems in sustainability science: the multi-level DPSIR framework. Geoforum 41:479-488. https://doi.org/10.1016/j.geoforum.2009.12.005

Olson, S. H., R. Gangnon, G. A. Silveira, and J. A. Patz. 2010. Deforestation and malaria in Mâncio Lima County, Brazil. Emerging Infection Diseases 16:1108-1115. https://dx.doi. org/10.3201\%2Feid1607.091785

Olsson, P., L. H. Gunderson, S. R. Carpenter, P. Ryan, L. Lebel, C. Folke, and C. S. Holling. 2006. Shooting the rapids: navigating transitions to adaptive governance of social-ecological systems. Ecology and Society 11(1):18. https://doi.org/10.5751/ES-01595-110118

Pereira, H. M., T. Domingos, and L. Vicente, editors. 2004. Portugal Millennium Ecosystem Assessment: state of the assessment report. Centro de Biologia Ambiental, Faculdade de Ciências da Universidade de Lisboa, Lisbon, Portugal.

Pinto, R., V. N. de Jonge, and J. C. Marques. 2014. Linking biodiversity indicators, ecosystem functioning, provision of services and human well-being in estuarine systems: application of a conceptual framework. Ecological Indicators 36:644-655. https://doi.org/10.1016/j.ecolind.2013.09.015

Reid, P. C., R. E. Hari, G. Beaugrand, D. M. Livingstone, C. Marty, D. Straile, J. Barichivich, E. Goberville, R. Adrian, Y. Aono, R. Brown, J. Foster, P. Groisman, P. Hélaouët, H.-H. Hsu, R. Kirby, J. Knight, A. Kraberg, J. Li , T.-T. Lo, R. B. Myneni, R. P. North, J. A. Pounds, T. Sparks, R. Stübi, Y. Tian, K. H. Wiltshire, D. Xiao, and Z. Zhu. 2016. Global impacts of the 1980s regime shift. Global Change Biology 22:682-703. https://doi. org/10.1111/gcb.13106

Reyers, B., R. Biggs, G. S. Cumming, T. Elmqvist, A. P. Hejnowicz, and S. Polasky. 2013. Getting the measure of ecosystem services: a social-ecological approach. Frontiers in Ecology and Environment 11:268-273. https://doi.org/10.1890/120144

Ringold, P. L., J. Boyd, D. Landers, and M. Weber. 2013. What data should we collect? A framework for identifying indicators of ecosystem contributions to human well-being. Frontiers in Ecology and the Environment 11:98-105. https://doi.org/10.1890/110156

Rocha, J. C., G. D. Peterson, and R. Biggs. 2015. Regime shifts in the Anthropocene: drivers, risks, and resilience. PLOS ONE 10: e0134639. https://doi.org/10.1371/journal.pone.0134639

Rounsevell, M. D. A., T. P. Dawson, and P. A. Harrison. 2010. A conceptual framework to assess the effects of environmental change on ecosystem services. Biodiversity and Conservation 19:2823-2842. https://doi.org/10.1007/s10531-010-9838-5

Salvia, R., and G. Quaranta. 2015. Adaptive cycle as a tool to select resilient patterns of rural development. Sustainability 7:11114-11138. https://doi.org/10.3390/su70811114

Santos-Martín, F., B. Martín-Lopez, M. García-Llorente, M. Aguado, J. Benayas, and C. Montes. 2013. Unraveling the relationships between ecosystems and human wellbeing in Spain. PLoS ONE 8:e73249. https://doi.org/10.1371/journal.pone.0073249

Scholes, R. J., B. Reyers, R. Biggs, M. J. Spierenburg, and A. Duriappah. 2013. Multi-scale and cross-scale assessments of social-ecological systems and their ecosystem services. Current Opinion in Environmental Sustainability 5:16-25. https://doi. org/10.1016/j.cosust.2013.01.004

Seidou, O., J. J. Asselin, and T. B. M. J. Ouarda. 2007. Bayesian multivariate linear regression with application to change point models in hydrometeorological variables. Water Resources Research 43:W08401. https://doi.org/10.1029/2005WR004835

Selomane, O., B. Reyers, R. Biggs, H. Tallis, and S. Polasky. 2015. Towards integrated social-ecological sustainability indicators: exploring the contribution and gaps in existing global data. Ecological Economics 118:140-146. https://doi.org/10.1016/j. ecolecon.2015.07.024

Spanish National Ecosystem Assessment. 2013. Ecosystems and biodiversity for human wellbeing. Synthesis of the key findings. Biodiversity Foundation of the Spanish Ministry of Agriculture, Food and Environment, Madrid, Spain.

ter Braak, C. J. F. 1992. Permutation versus bootstrap significance tests in multiple regression and ANOVA. Pages 79-85 in K.-H. Jöckel, G. Rothe, and W. Sendler, editors. Bootstrapping and related techniques. Springer Verlag, Berlin, Germany. https://doi. org/10.1007/978-3-642-48850-4 10

UK National Ecosystem Assessment. 2011. The UK National Ecosystem Assessment: synthesis of the key findings. United Nations Environment Programme-World Conservation Monitoring Centre Cambridge, UK.

Walker, B., C. S. Holling, S. R. Carpenter, and A. Kinzig. 2004. Resilience, adaptability and transformability in social-ecological systems. Ecology and Society 9(2):5. [online] URL: http://www. ecologyandsociety.org/vo19/iss2/art5/ 
Appendix 1. List of indicators.

Table A1.1. Biodiversity indicators description and evolution based on the Red list Index of threatened species of vertebrates in Spain.

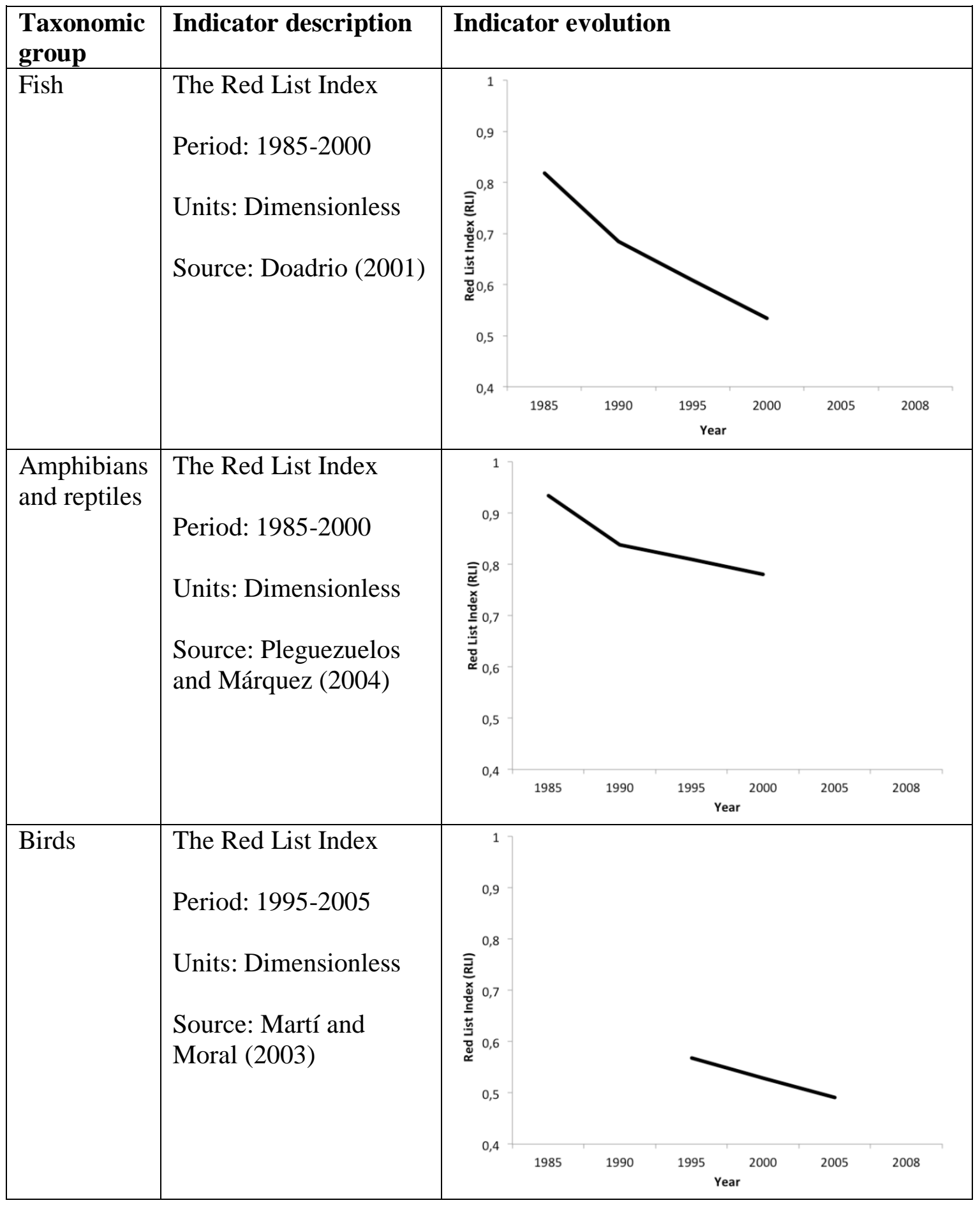




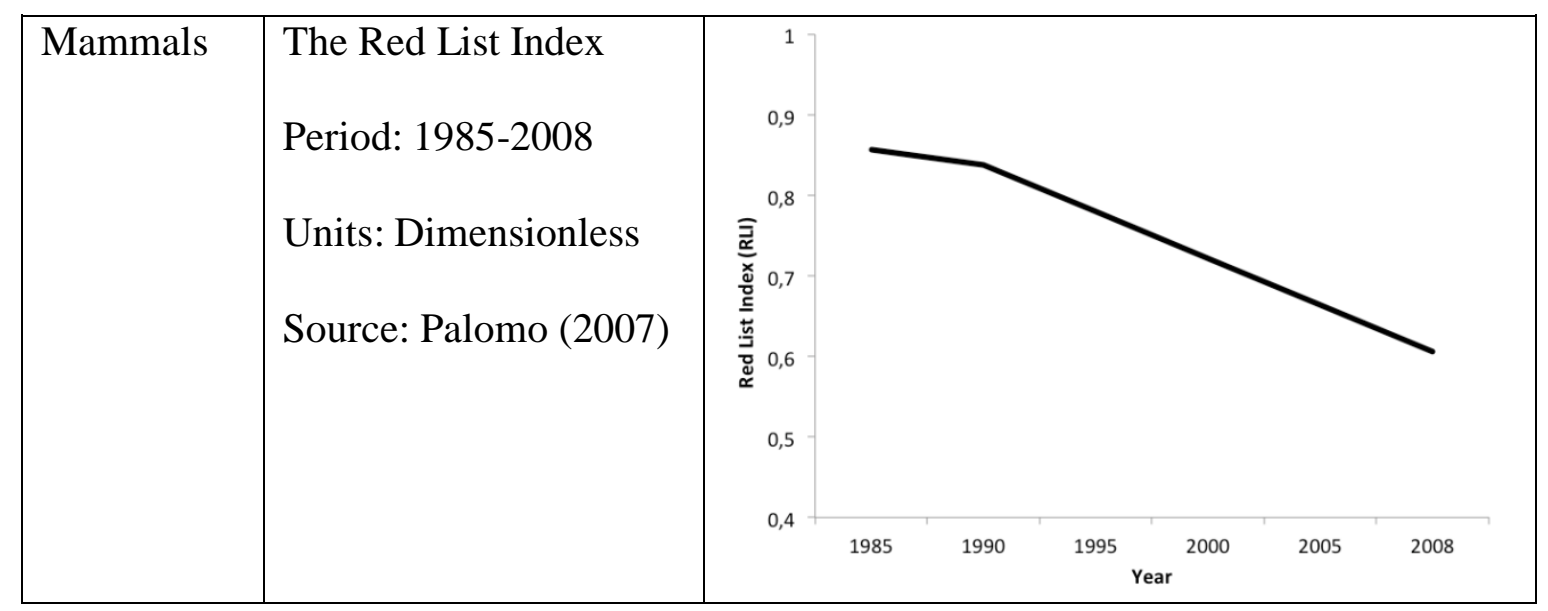

\section{REFERENCES}

Doadrio, I. (2001) Atlas y Libro Rojo de los Peces Continentales de España National Museum of Natural Science. General Direction of Nature Conservation, Madrid.

Martí, R. and Moral, J. C. (2003) Atlas de las Aves Reproductoras De España. The Spanish Ministry of the Environment (Autonomous Organism of Nature Reserves) and Spanish Ortnithologist Society, Madrid, Spain.

Palomo, J. L. (2007) Atlas y Libro Rojo de los mamíferos terrestres de España. The Spanish Ministry of the Environment, Autonomous Organism of Nature Reserves, Madrid, Spain.

Pleguezuelos, J. M. and Márquez, R. (2004) Atlas y Libro Rojo de los Anfibios y Reptiles de España. National Museum of Natural Science. General Direction of Nature Conservation, Madrid, Spain.

Table A1.2. List of Ecosystem Services indicators selected for the analysis that include the following information: description, data source, measurement unit, timeline used based on the available data, rationale and graphical evolution of the trend indicators. 


\begin{tabular}{|c|c|c|}
\hline $\begin{array}{l}\text { Ecosystem } \\
\text { Services }\end{array}$ & $\begin{array}{l}\text { Indicator } \\
\text { description }\end{array}$ & Indicator evolution \\
\hline \multicolumn{3}{|l|}{ Provisioning } \\
\hline \multicolumn{3}{|l|}{ Nutrition } \\
\hline Crops & 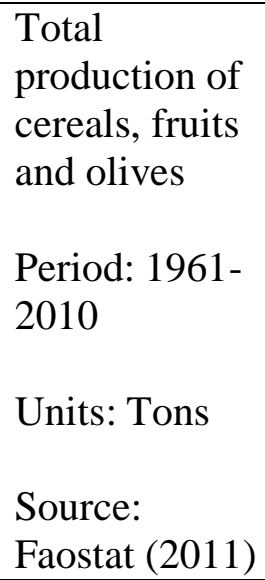 & 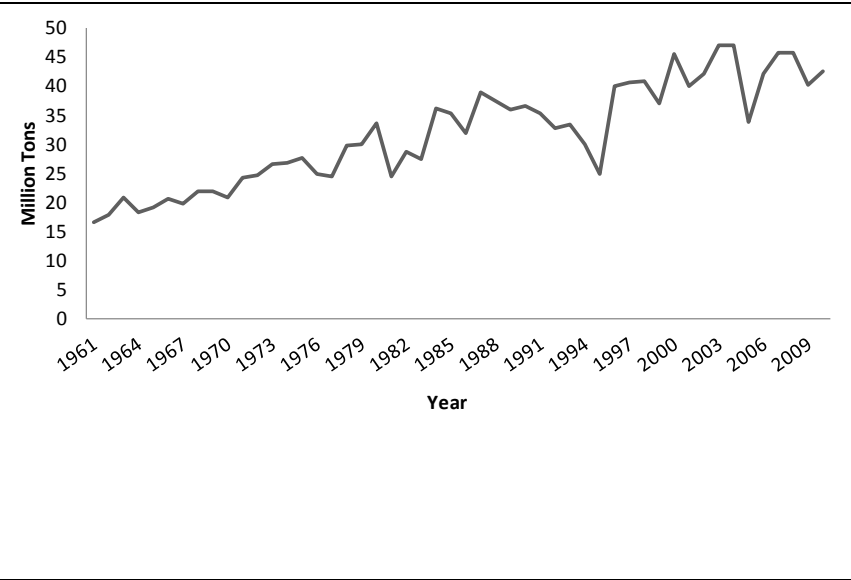 \\
\hline Livestock & $\begin{array}{l}\text { Total } \\
\text { production of } \\
\text { meat } \\
\text { Period: } 1961- \\
2010 \\
\text { Units: Tons } \\
\text { Source: } \\
\text { Faostat (2011) }\end{array}$ & 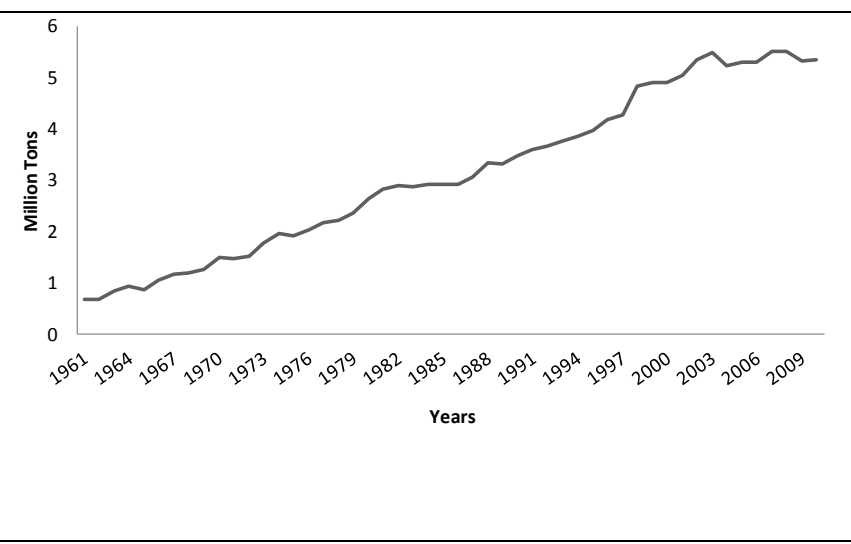 \\
\hline $\begin{array}{l}\text { Wild plants } \\
\text { and animals } \\
\text { and their } \\
\text { products }\end{array}$ & $\begin{array}{l}\text { Number of } \\
\text { beehives of } \\
\text { Apis melifera } \\
\text { Period: } 1961- \\
2008 \\
\text { Units: } \mathrm{N}^{\mathrm{o}} \\
\text { beehives } \\
\text { Source: } \\
\text { Faostat (2011) }\end{array}$ & 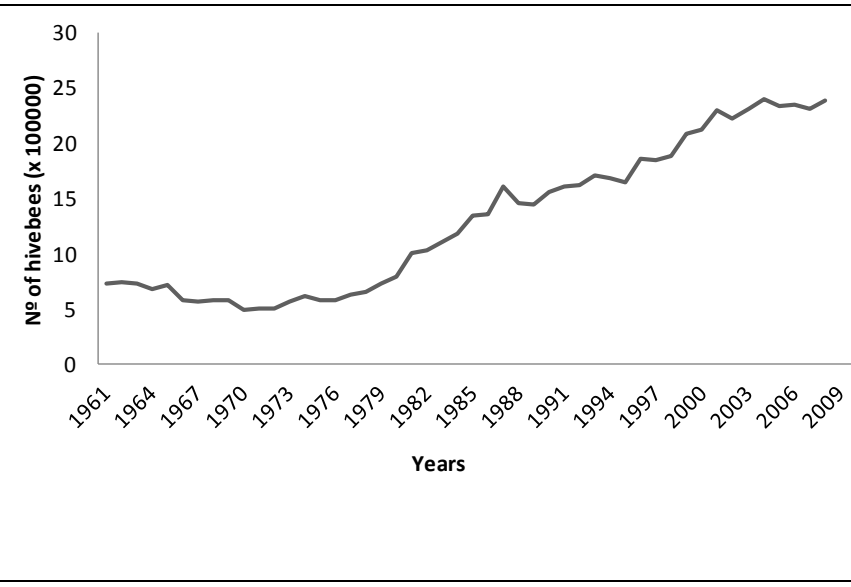 \\
\hline \multicolumn{3}{|c|}{ Biotic materials } \\
\hline Timber & $\begin{array}{l}\text { Total wood } \\
\text { production } \\
\text { Period: } 1961- \\
2009 \\
\text { Units: Million } \\
\mathrm{m}^{3} \\
\text { Source: }\end{array}$ & 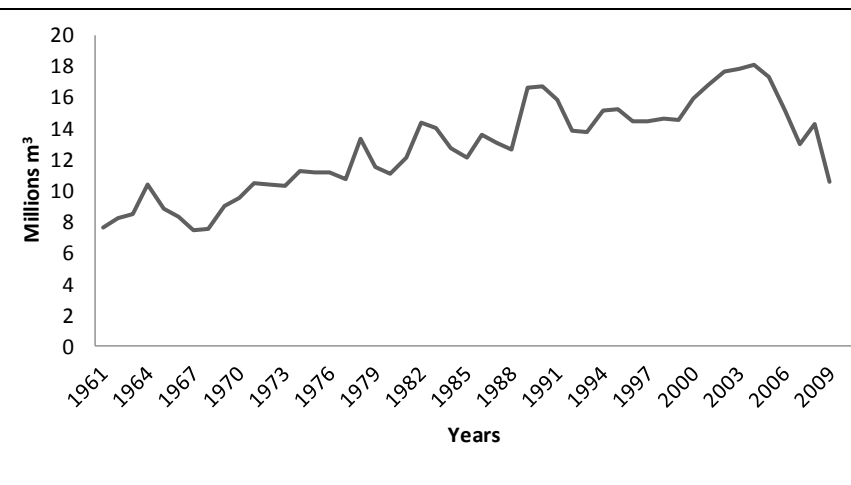 \\
\hline
\end{tabular}




\begin{tabular}{|c|c|c|}
\hline & $\begin{array}{l}\text { Spanish } \\
\text { Ministry of } \\
\text { Agriculture } \\
\text { Food and } \\
\text { Environment } \\
\text { (2011) }\end{array}$ & \\
\hline \multicolumn{3}{|l|}{ Regulation } \\
\hline \multicolumn{3}{|c|}{ Regulation of physic-chemical environment } \\
\hline $\begin{array}{l}\text { Maintenance } \\
\text { of soil } \\
\text { fertility }\end{array}$ & $\begin{array}{l}\text { Fertilizer } \\
\text { consumption } \\
\text { Period: 1961- } \\
2007 \\
\text { Units: } \\
\text { Kilograms per } \\
\text { hectare of } \\
\text { arable land } \\
\text { Source: World } \\
\text { Bank (2011) }\end{array}$ & 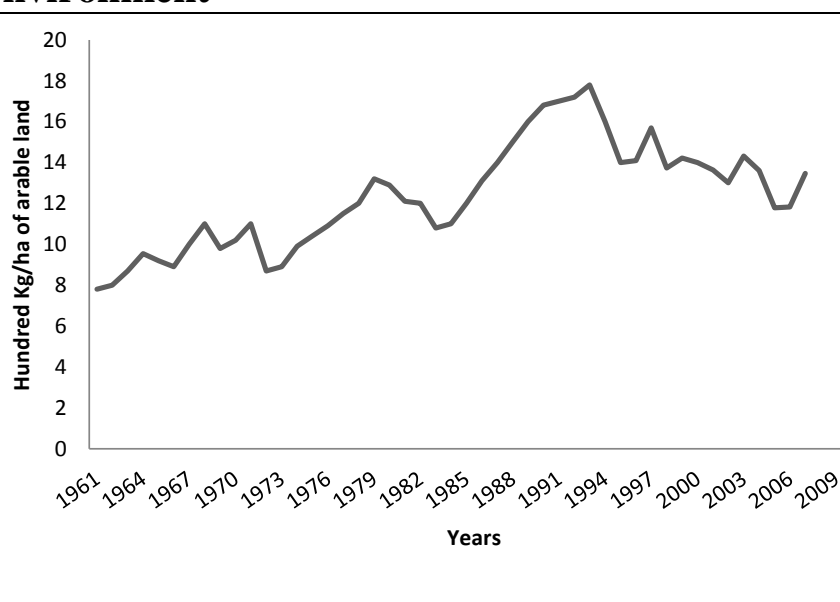 \\
\hline \multicolumn{3}{|c|}{ Flow regulation } \\
\hline $\begin{array}{l}\text { Water flow } \\
\text { regulation }\end{array}$ & $\begin{array}{l}\text { Damages due } \\
\text { to floods paid } \\
\text { by insurance } \\
\text { companies } \\
\text { Period: 1971- } \\
2007 \\
\text { Units: } \\
\text { Thousands of } \\
\text { expedients per } \\
\text { year } \\
\text { Source: } \\
\text { Insurance } \\
\text { Compensation } \\
\text { Consortium } \\
\text { (2011) }\end{array}$ & 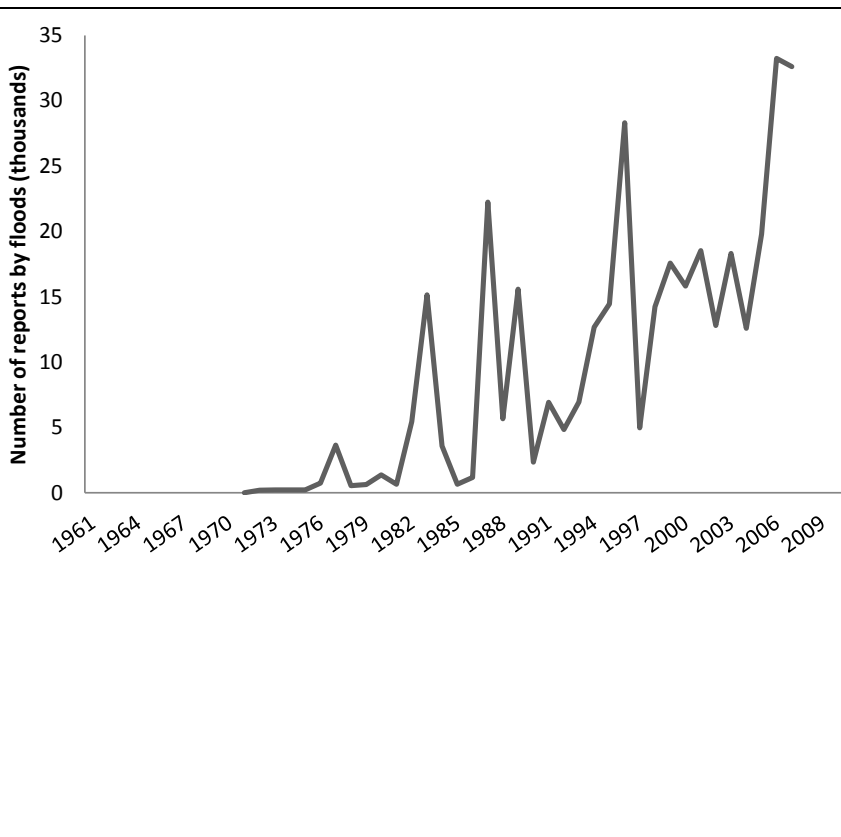 \\
\hline
\end{tabular}




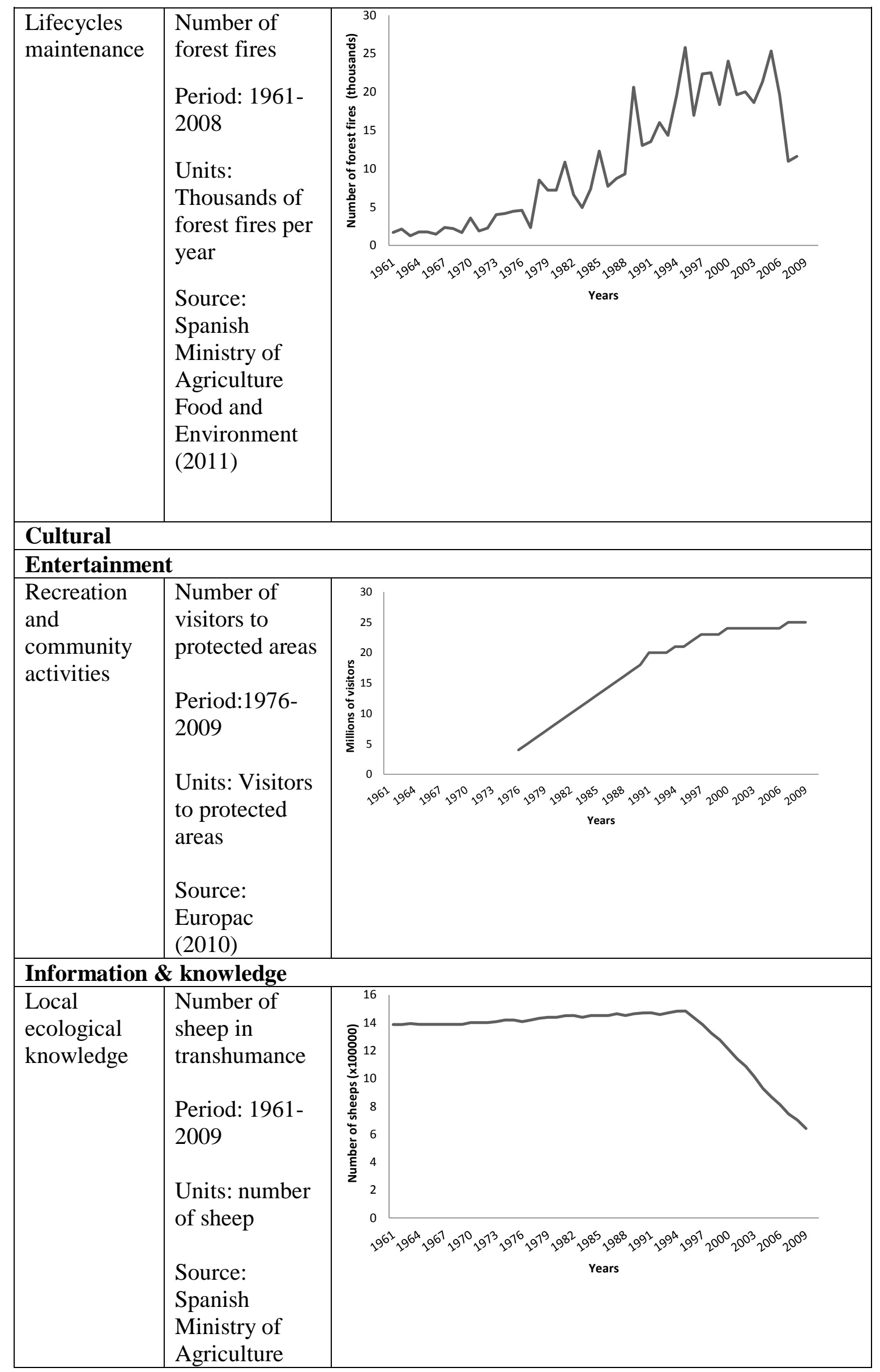




\begin{tabular}{|l|l|l|}
\hline & $\begin{array}{l}\text { Food and } \\
\text { Environment } \\
(2011)\end{array}$ & \\
\hline
\end{tabular}

\section{REFERENCES}

Europac (2010) Anuario EUROPARC-España del estado de los espacios naturales protegidos 2010. FUNGOBE, Madrid 104.

Faostat (2011) Food and Agriculture Organization of the United Nations. Statistical division. Available online. Visited November 2011. http://faostat.fao.org.

Spanish Ministry of Agriculture Food and Environment (2011) de, A. estadistica. Perfil ambiental de España. Visited November 2011.

http://www.magrama.gob.es/es/estadistica/temas/default.aspx.

Insurance Compensation Consortium (2011) Visited November 2011.

http://www.consorseguros.es/web/guest/i.

World Bank (2011) World Bank data by country. Visited November 2011.

http://data.worldbank.org/country/spain. 
Table A1.3. Description of human wellbeing indicators and their evolution in the following five dimensions: material, health, security, freedom and social relations.

\begin{tabular}{|c|c|c|}
\hline $\begin{array}{l}\text { Human } \\
\text { wellbeing }\end{array}$ & Indicator description & Indicator evolution \\
\hline \multicolumn{3}{|c|}{ Health / Physical } \\
\hline $\begin{array}{l}\text { Life } \\
\text { expectanc } \\
y \text { at birth }\end{array}$ & $\begin{array}{l}\text { Average numbers of } \\
\text { years a newborn child } \\
\text { would live if the } \\
\text { current mortality } \\
\text { patterns remained the } \\
\text { same } \\
\text { Period: 1961-2010 } \\
\text { Units: years } \\
\text { Source: World Bank } \\
\text { (2011) }\end{array}$ & 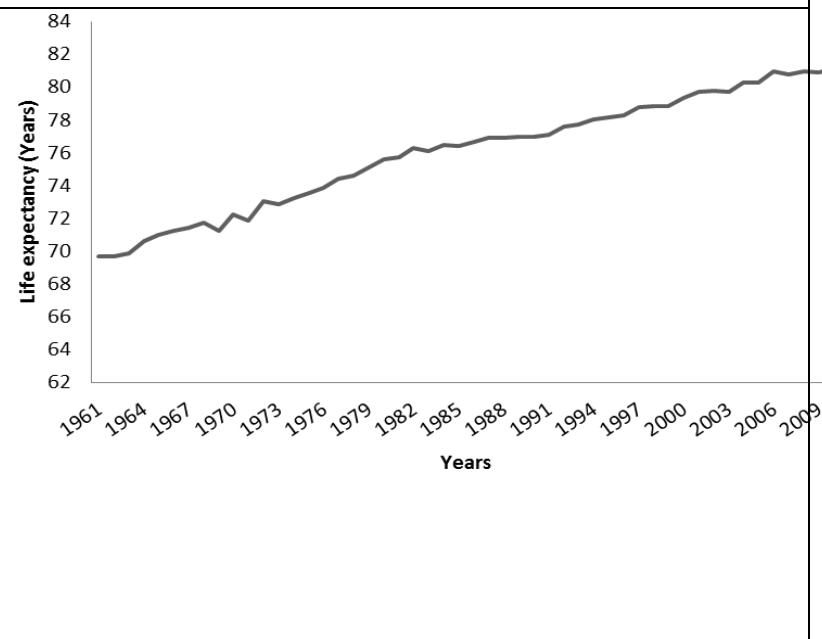 \\
\hline \multicolumn{3}{|c|}{ Material / Access to goods } \\
\hline $\begin{array}{l}\text { Domestic } \\
\text { material } \\
\text { consumpt } \\
\text { ion }\end{array}$ & $\begin{array}{l}\text { Physical materials that } \\
\text { are mobilized each } \\
\text { year to support an } \\
\text { economy } \\
\text { Period: } 1961-2010 \\
\text { Units: Ton per } \\
\text { inhabitant } \\
\text { Source: Carpintero } \\
\text { (2005) }\end{array}$ & 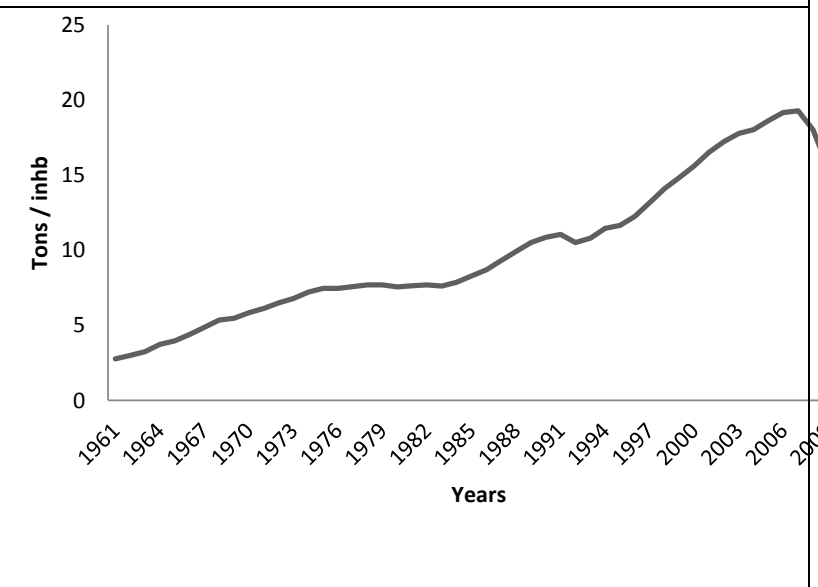 \\
\hline
\end{tabular}

\section{REFERENCES}

Carpintero, O. (2005) El metabolismo de la economía española. Recursos naturales y huella ecológica (1955-2000). Fundación César Manrique.

World Bank (2011) World Bank data by country. Visited November 2011. http://data.worldbank.org/country/spain. 
Table A1.4. Description of indicators of response options and their evolution in a Spanish institution dealing with environmental issues.

\begin{tabular}{|c|c|c|}
\hline $\begin{array}{l}\text { Response } \\
\text { options }\end{array}$ & $\begin{array}{l}\text { Indicator } \\
\text { description }\end{array}$ & Indicator evolution \\
\hline \multicolumn{3}{|c|}{ Biodiversity conservation } \\
\hline $\begin{array}{l}\text { Number of } \\
\text { protected } \\
\text { areas }\end{array}$ & $\begin{array}{l}\text { Total number of } \\
\text { protected areas } \\
\text { declared } \\
\text { Period: 1962-2010 } \\
\text { Units: number of } \\
\text { protected areas } \\
\text { Source: Spanish } \\
\text { Ministry of } \\
\text { Agriculture Food and } \\
\text { Environment (2011) }\end{array}$ & 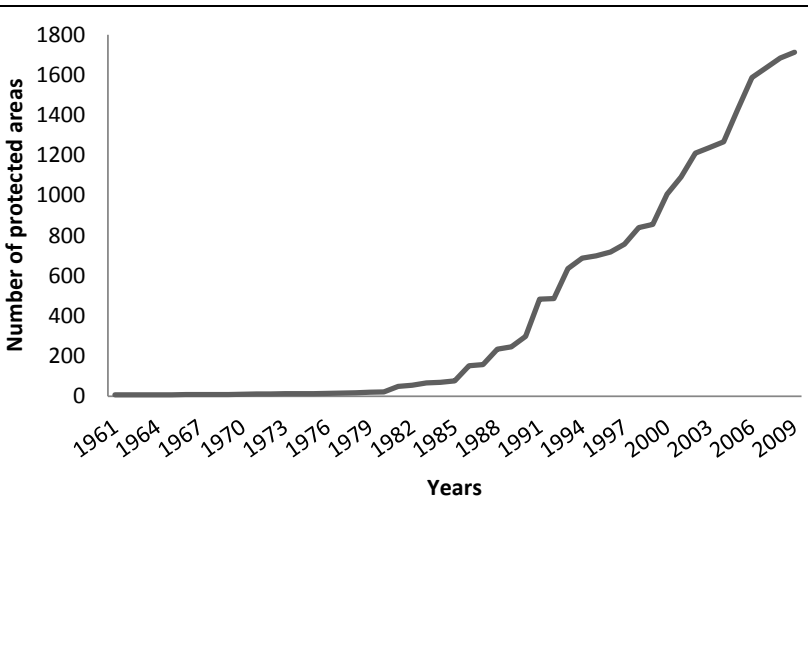 \\
\hline
\end{tabular}

\section{REFERENCES}

Spanish Ministry of Agriculture Food and Environment (2011) Anuraio de estadistica.

Perfil ambiental de España. Visited November 2011.

http://www.magrama.gob.es/es/estadistica/temas/default.aspx. 
Table A1.5. Description of driver indicators that indirectly affect biodiversity and ecosystems in Spain and their evolution.

\begin{tabular}{|c|c|c|}
\hline Drivers & $\begin{array}{l}\text { Indicator } \\
\text { description }\end{array}$ & Indicator evolution \\
\hline \multicolumn{3}{|l|}{ Economic } \\
\hline Total GDP & $\begin{array}{l}\text { Gross domestic } \\
\text { product } \\
\text { Period: 1961-2008 } \\
\text { Units: Millions of \$ } \\
\text { PPP } \\
\text { Source: World } \\
\text { Bank (2011) }\end{array}$ & 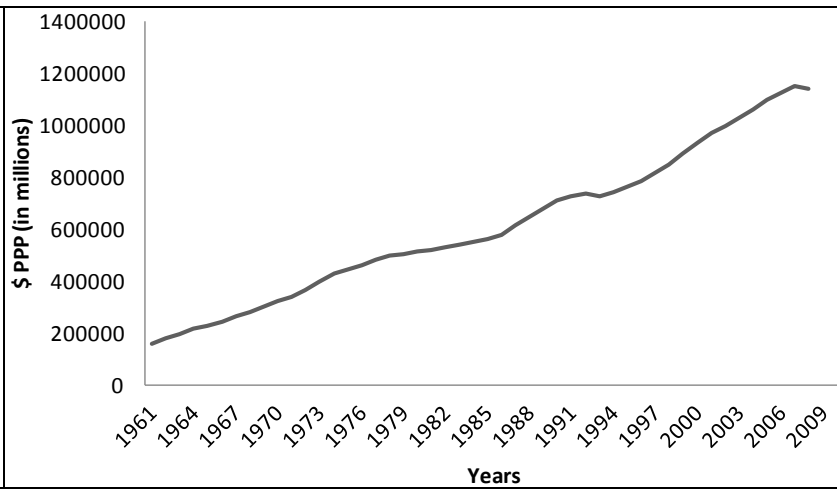 \\
\hline \multicolumn{3}{|c|}{ Demographic } \\
\hline $\begin{array}{l}\text { Population } \\
\text { density }\end{array}$ & $\begin{array}{l}\text { Human population } \\
\text { density } \\
\text { Period: } 1961-2010 \\
\text { Units: Persons per } \\
\text { squared kilometer } \\
\text { Source: World } \\
\text { Bank (2011) }\end{array}$ & 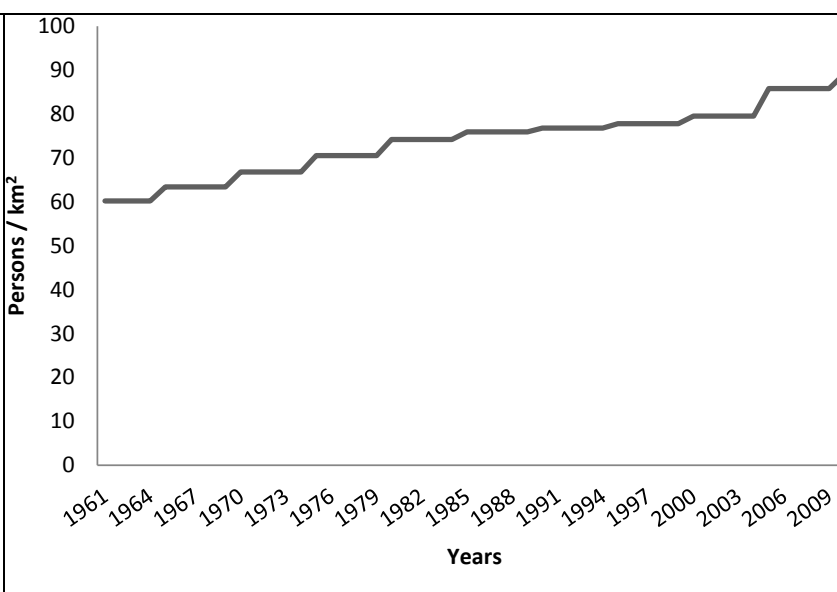 \\
\hline \multicolumn{3}{|c|}{ Scientific and technological } \\
\hline $\begin{array}{l}\text { Investments } \\
\text { in R\&D } \\
\text { programs }\end{array}$ & $\begin{array}{l}\text { Investment in R\&D } \\
\text { programs } \\
\text { Period: } 1967-2009 \\
\text { Units: \% (from } \\
\text { GDP) } \\
\text { Source: Spanish } \\
\text { National Statistical } \\
\text { Institute (2011) }\end{array}$ & 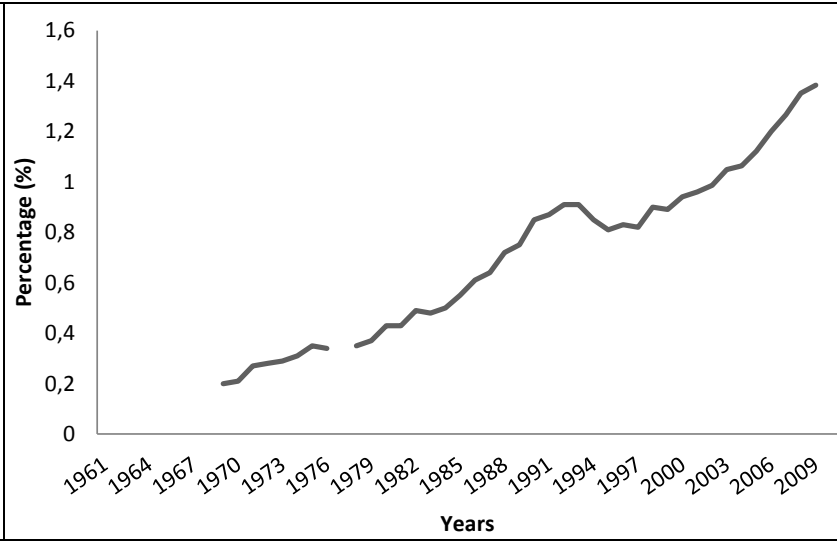 \\
\hline
\end{tabular}

\section{REFERENCES}


Spanish National Statistical Institute. Visited November 2011. http://www.ine.es.

World Bank (2011) World Bank data by country. Visited November 2011.

http://data.worldbank.org/country/spain. 
Table A1.6. Description of pressure indicators that directly affect biodiversity and ecosystems in Spain and their evolution.

\begin{tabular}{|c|c|c|}
\hline Pressures & $\begin{array}{l}\text { Indicator } \\
\text { description }\end{array}$ & Indicator evolution \\
\hline \multicolumn{3}{|c|}{ Land use change } \\
\hline Urbanization & $\begin{array}{l}\text { Number of initiated } \\
\text { houses } \\
\text { Period: } 1970-2009 \\
\text { Units: Thousands of } \\
\text { initiated houses } \\
\text { Source: Spanish } \\
\text { National Statistical } \\
\text { Institute (2011) }\end{array}$ & 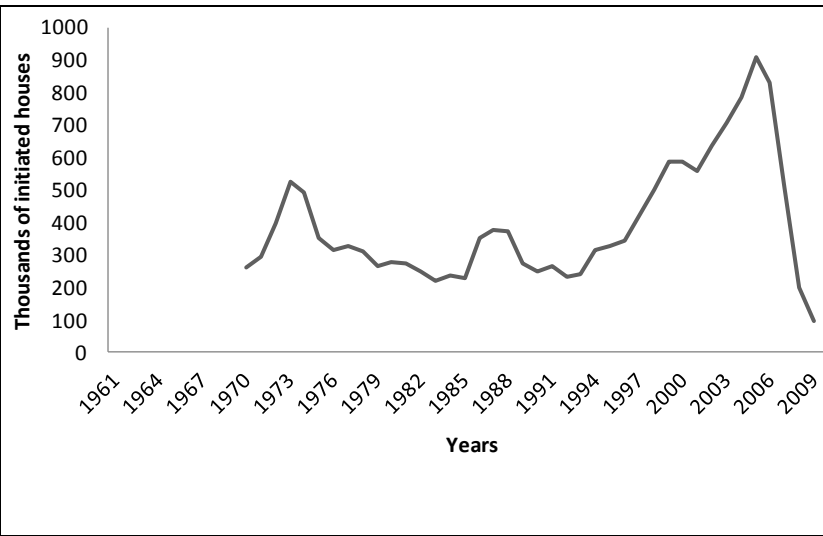 \\
\hline \multicolumn{3}{|c|}{ Overexploitation / Biotic materials } \\
\hline $\begin{array}{l}\text { Species } \\
\text { extracted }\end{array}$ & $\begin{array}{l}\text { Captures of salmons } \\
\text { in Spanish rivers } \\
\text { Period: } 1961-2005 \\
\text { Units: Millions of } \\
\text { tons } \\
\text { Source: Sport } \\
\text { Fishing Groups } \\
\text { (2011) }\end{array}$ & 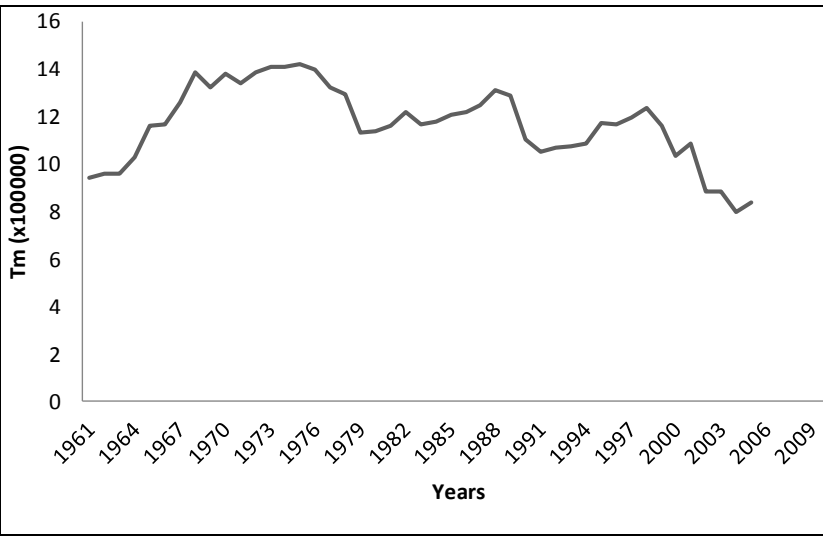 \\
\hline \multicolumn{3}{|c|}{ Over exploitation / Abiotic materials } \\
\hline $\begin{array}{l}\text { Groundwater } \\
\text { consumption }\end{array}$ & $\begin{array}{l}\begin{array}{l}\text { Groundwater } \\
\text { extracted for } \\
\text { irrigation }\end{array} \\
\text { Period: } 1961-2004 \\
\text { Units: Hectometers } \\
\text { Source: Spanish } \\
\text { Ministry of } \\
\text { Agriculture Food } \\
\text { and Environment } \\
\text { (2011) }\end{array}$ & 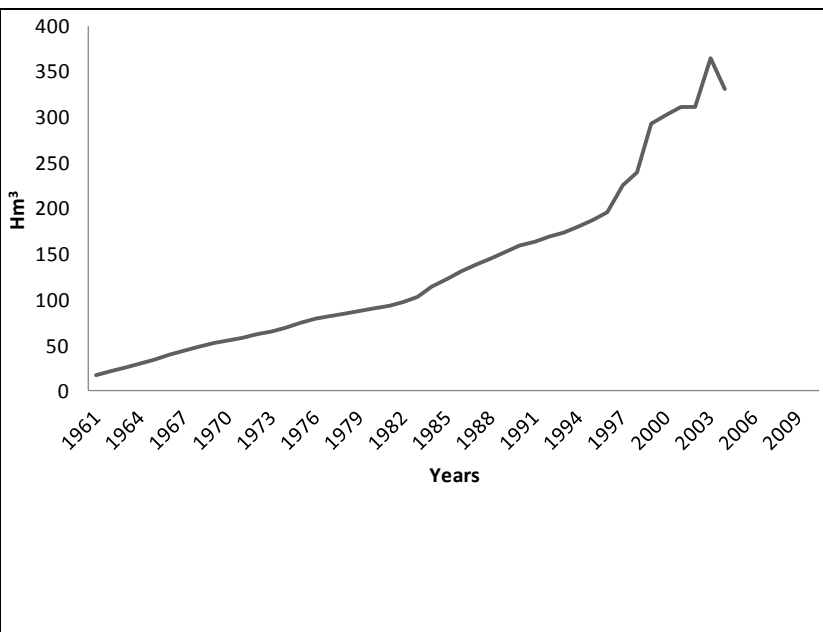 \\
\hline Pollution & & \\
\hline
\end{tabular}




\begin{tabular}{|c|c|c|}
\hline Pollution & $\begin{array}{l}\text { Total } \mathrm{CO}_{2} \text { emissions } \\
\text { Period: } 1961-2010 \\
\text { Units: Millions of } \\
\text { tons } \\
\text { Source: Carbon } \\
\text { Dioxide Information } \\
\text { Analysis Center } \\
\text { (2011) }\end{array}$ & 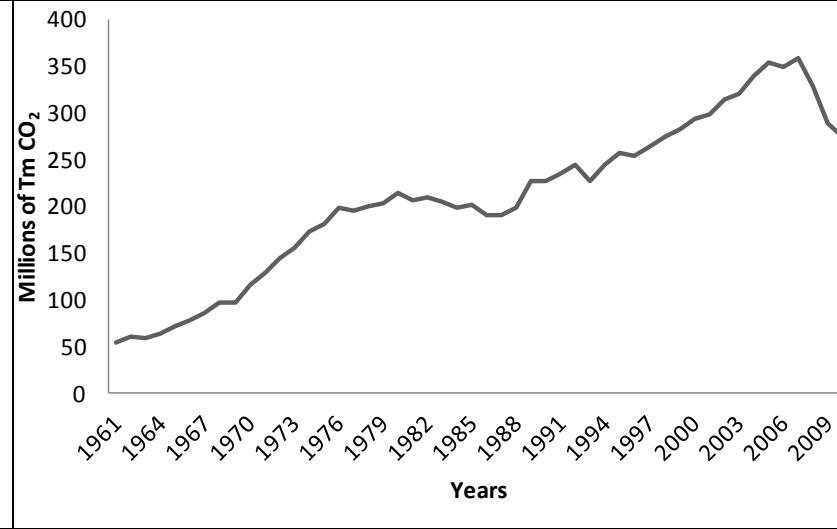 \\
\hline \multicolumn{3}{|c|}{ Invasive alien species } \\
\hline $\begin{array}{l}\text { Invasive alien } \\
\text { Species }\end{array}$ & $\begin{array}{l}\text { Number of invasive } \\
\text { alien plants } \\
\text { Period: } 1961-2005 \\
\text { Units: Number of } \\
\text { invasive alien plants } \\
\text { Source: Sanz et al. } \\
\text { (2004) }\end{array}$ & 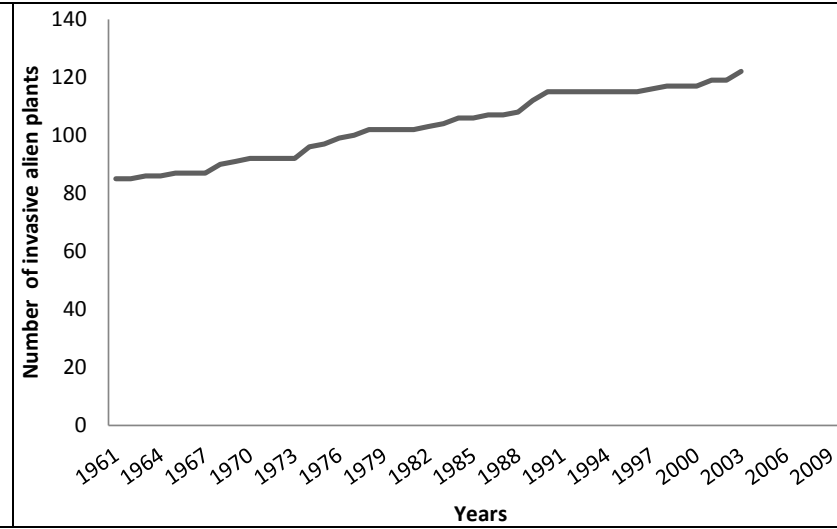 \\
\hline
\end{tabular}

\section{REFERENCES}

Carbon Dioxide Information Analysis Center (2011) Visited November 2011. http://cdiac.ornl.gov.

Sanz Elorza, M., Sanchez, E. D. and Sobrino Vesperina, E. (2004) Atlas de las plantas alóctonas invasoras en España. Dirección General para la Biodiversidad, Madrid. 384 p.

Spanish National Statistical Institute. Visited November 2011. http://www.ine.es.

Spanish Ministry of Agriculture Food and Environment (2011) Anuraio de estadistica.

Perfil ambiental de España. Visited November 2011.

http://www.magrama.gob.es/es/estadistica/temas/default.aspx.

Sport Fishing Groups (2011) Visited November 2011.

http://www.vadeando.com/inicio/. 